Original Research Pape

\title{
Presents the Kinematics of a Manipulator with Three Mobilities
}

\author{
Relly Victoria Virgil Petrescu \\ ARoTMM-IFToMM, Bucharest Polytechnic University, Bucharest, (CE), Romania
}

\section{Article history}

Received: $17-03-2020$

Revised: 28-03-2020

Accepted: 29-05-2020

Email: rvvpetrescu@gmail.com

\begin{abstract}
The paper briefly presents the kinematic study of a manipulator with three mobilities, which can be used both in industrial halls and in garages, depending on its suitably chosen constructive size, which at smaller dimensions can be handled very easily. This manipulator can carry large loads, thus easing the work of the human being and preventing it from major dangers that can occur during the transport of large pieces and a large mass.
\end{abstract}

Keywords: Robots, Mechatronic Systems, Structure, Kinematics, Machines, Balancing

\section{Introduction}

In the industrial halls it is often necessary to handle large objects, with a large and large table, which have to be transported not over long distances but moved from one place to another, raised, then lowered to various levels, left or right. Such repeated manipulations of 7 heavy and dangerous objects can be done only with the help of a manipulator, which can be a crane, a specially designed trolley, a complicated robot or a simple manipulator as is the case for the one presented in the paper.

Workers are prevented from using it to get various diseases because of the repeated lifting of heavy objects. In the past, an interior crane built on different systems walks through the respective hall to carry the heavy objects.

The system was cumbersome to operate and even a little dangerous without permanent attention to the fact that it is moving so that workers can be warned permanently about its movements. Such expensive and difficult systems to handle and maintain are today generally on the verge of extinction, because the vast majority of industrial operations have been taken over by specialized intelligent robots, but in some places a manipulator may be needed which can be automated or manually depending by the size of the place where it is implemented.

In the maritime ports there are still used systems with large cranes, but also there the systems that traveled on large surfaces began to reduce or even disappear, being replaced by the individual, punctual cranes, some of them even being robotic, specialized on different unloading-loading operations.

The swivel crane with ECO5 column is extremely easy to handle, it provides convenient access to all points of the space, with a pivoting angle of maximum $270^{\circ}$, being the indispensable accessory of all workstations.

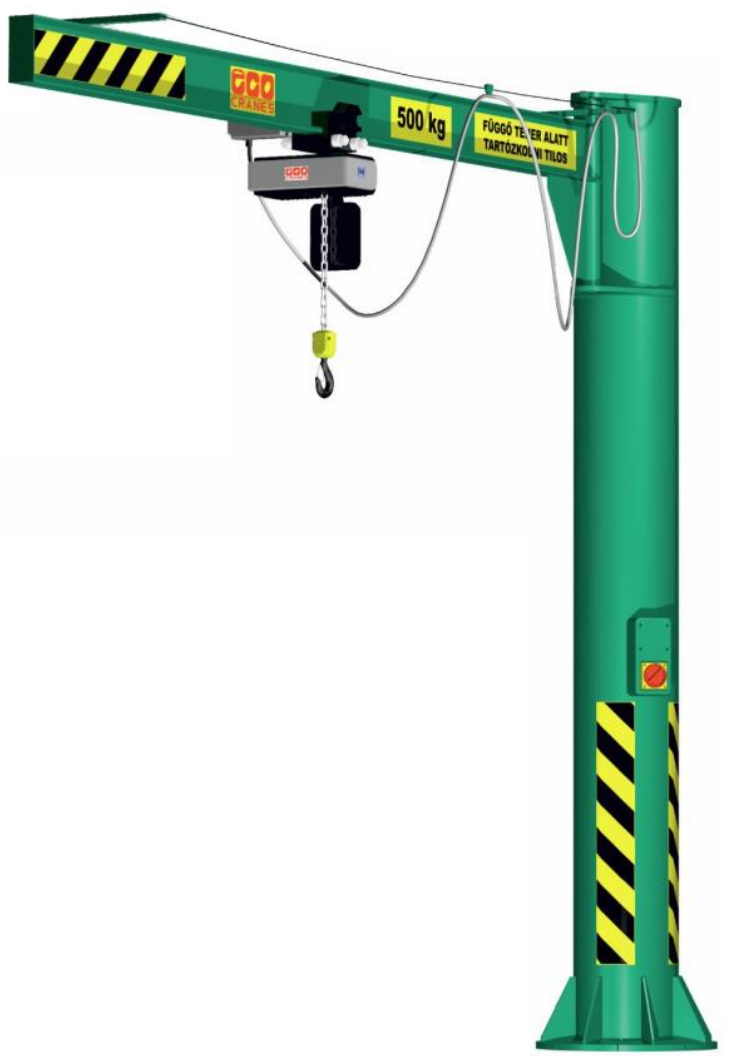

Fig. 1: The crane with ECO5 column is extremely easy to handle, it provides convenient access to all points of the space, with a pivoting angle of maximum $270^{\circ}$, being the indispensable accessory of all workstations 


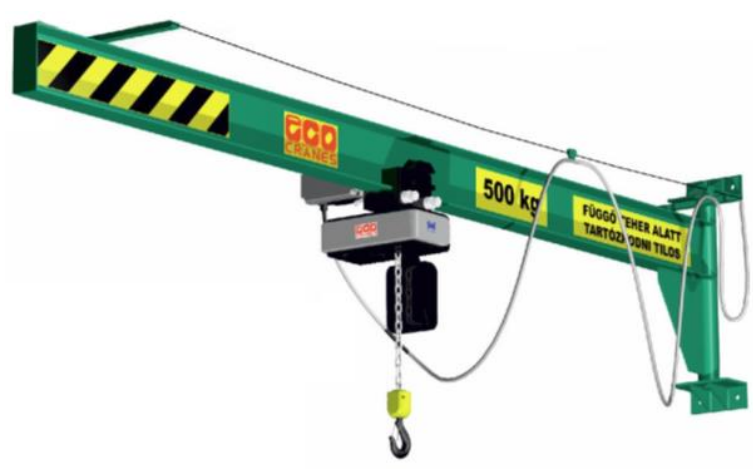

Fig. 2: The ECO3 pivoting wall crane

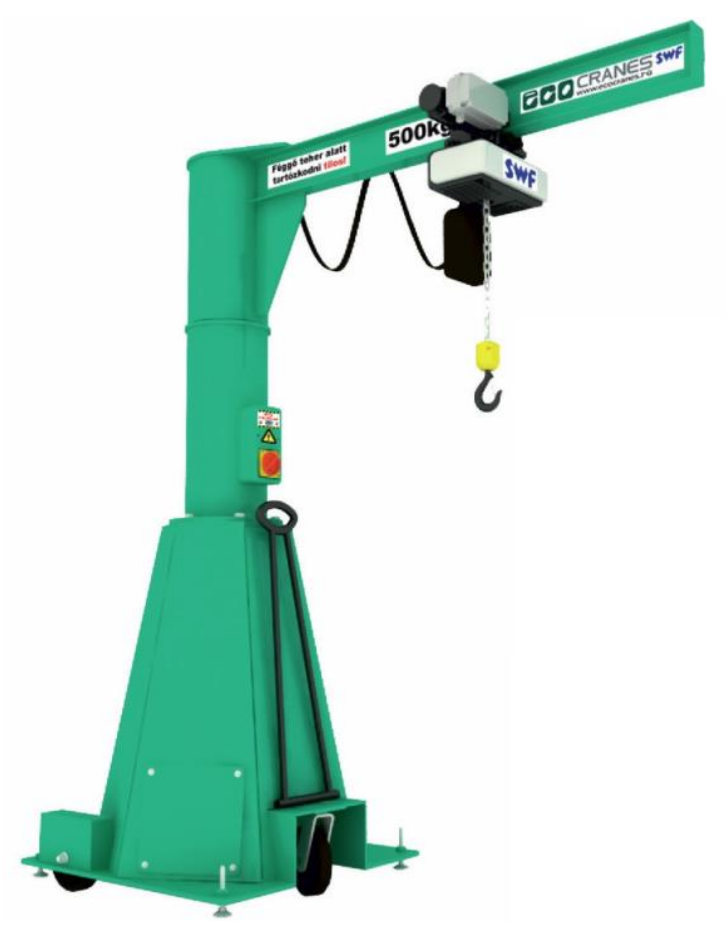

Fig. 3: The ECO6 mobile pivoting crane

Manufactured from rigid torsion steel, fixed by means of anchor bolts to the concrete foundation. Up to $2 \mathrm{~m}$, the electricity supply is made in the cable tube, with a rubber cable of circular diameter, in the case of the arm with larger openings with the help of the $\mathrm{C}$ rail, with a cable trolley and a flat cable. The power switch is mounted on the column (Fig. 1).

The ECO3 pivoting wall crane is extremely easy to handle, with a pivoting angle of maximum $180^{\circ}$, being the indispensable accessory of all workplaces. Thanks to the height-mounted console, it makes optimal use of the lifting height even in the lower rooms. Made of rigid profile steel at torsion, fixed by the console to a steel beam, concrete pole. Up to $2 \mathrm{~m}$, the electricity supply is made in the cable tube, with a rubber cable of circular diameter, in the case of the arm with larger openings with the help of the $\mathrm{C}$ rail, with a cable trolley and a flat cable (Fig. 2).

The ECO6 mobile pivoting crane is successfully folded to different situations in the factory. It can be moved manually to the desired location and fastened with the support screws. It has a lifting capacity of up to $500 \mathrm{~kg}$ and a pivoting angle of $360^{\circ}$. The electricity supply is made using the contacts through the collector rings.

For lifting loads, this variant requires filling the body of the crane with counterweights (Fig. 3).

The ECO6 mobile pivoting crane is successfully folded to different situations within a section, halls, factories, or even in a hangar, or larger garage, which can be moved manually to the desired location and fixed with the support screws, having a capacity of lifting up to $500 \mathrm{~kg}$. Such a crane model was inspired by modern manipulative robots, which instead of the drilling, welding, handling, dyeing, crane system was added. Its advantage is that it can be more penetrating, like a specialized robot, but with a lower purchase price than robotic systems.

Such a crane is generally easier to handle itself, to implement, to use, to maintain and also to have a lower purchase price, which is often more convenient than robotization, where handling of heavy objects and bulky is necessary, but not the automation of the operation itself (Aabadi, 2019; Antonescu and Petrescu, 1985; 1989; Antonescu et al., 1985a; 1985b; 1986; 1987; 1988; 1994; 1997; 2000a; 2000b; 2001; Aversa et al., 2017a; 2017b; 2017c; 2017d; 2017e; 2016a; 2016b; 2016c; 2016d; 2016e; 2016f; 2016g; 2016h; 2016i; 2016j; 2016k; 2016l; 2016m; 2016n; 2016o; Cao et al., 2013; Dong et al., 2013; Comanescu, 2010; Franklin, 1930; He et al., 2013; Lee, 2013; Lin et al., 2013; Liu et al., 2013; Padula and Perdereau, 2013; Perumaal and Jawahar, 2013; Petrescu, 2011; 2015a; 2015b; Petrescu and Petrescu, 1995a; 1995b; 1997a; 1997b; 1997c; 2000a; 2000b; 2002a; 2002b; 2003; 2005a; 2005b; 2005c; 2005d; 2005e; 2011a; 2011b; 2012a; 2012b; 2013a; 2013b; 2013c; 2013d; 2013e; 2016a; 2016b; 2016c; Petrescu et al., 2009; 2016a; 2016b; 2017a; 2017b; 2017c; 2017d; 2017e; 2017f; 2017g; 2017h; $2017 \mathrm{i} ; 2017 \mathrm{j} ; 2017 \mathrm{k} ; 2017 \mathrm{l} ; 2017 \mathrm{~m} ; 2017 \mathrm{n} ; 2017 \mathrm{o}$; $2017 \mathrm{p} ; 2017 \mathrm{q} ; 2017 \mathrm{r} ; 2017 \mathrm{~s} ; 2017 \mathrm{t} ; 2017 \mathrm{u} ; 2017 \mathrm{v}$; 2017w; 2017x; 2017y; 2017z; 2017aa; 2017ab; 2017ac; 2017ad; 2017ae; 2018a; 2018b; 2018c; 2018d; 2018e; 2018f; 2018g; 2018h; 2018i; 2018j; 2018k; 2018l; 2018m; 2018n; Rulkov et al., 2016; Agarwala, 2016; Babayemi, 2016; Ben-Faress et al., 2019; Gusti and Semin, 2016; Mohamed et al., 2016; Wessels and Raad, 2016; Maraveas et al., 2015; Khalil, 2015; RhodeBarbarigos et al., 2015; Takeuchi et al., 2015; Li et al., 2015; Vernardos and Gantes, 2015; Bourahla and 
Blakeborough, 2015; Stavridou et al., 2015a; Ong et al., 2015; Dixit and Pal, 2015; Rajput et al., 2016; Rea and Ottaviano, 2016; Zurfi and Zhang, 2016a-b; Zheng and Li, 2016; Buonomano et al., 2016a; 2016b; Faizal et al., 2016; Ascione et al., 2016; Elmeddahi et al., 2016; Calise et al., 2016; Morse et al., 2016; Abouobaida, 2016; Rohit and Dixit, 2016; Kazakov et al., 2016; Alwetaishi, 2016; Riccio et al., 2016a; 2016b; Iqbal, 2016; Hasan and El-Naas, 2016; Al-Hasan and AlGhamdi, 2016; Jiang et al., 2016; Sepúlveda, 2016; Martins et al., 2016; Pisello et al., 2016; Jarahi, 2016; Mondal et al., 2016; Mansour, 2016; Al Qadi et al., 2016b; Campo et al., 2016; Samantaray et al., 2016; Malomar et al., 2016; Rich and Badar, 2016; Hirun, 2016; Bucinell, 2016; Nabilou, 2016b; Barone et al., 2016; Bedon and Louter, 2016; Santos and Bedon, 2016; Fontánez et al., 2019; De León et al., 2019; Hypolite et al., 2019; Minghini et al., 2016; Bedon, 2016; Jafari et al., 2016; Orlando and Benvenuti, 2016; Wang and Yagi, 2016; Obaiys et al., 2016; Ahmed et al., 2016; Jauhari et al., 2016; Syahrullah and Sinaga, 2016; Shanmugam, 2016; Jaber and Bicker, 2016; Wang et al., 2016; Moubarek and Gharsallah, 2016; Amani, 2016; Shruti, 2016; Pérezde León et al., 2016; Mohseni and Tsavdaridis, 2016; Abu-Lebdeh et al., 2016; Serebrennikov et al., 2016; Budak et al., 2016; Augustine et al., 2016; Jarahi and Seifilaleh, 2016; Nabilou, 2016a; You et al., 2016; Al Qadi et al., 2016a; Rama et al., 2016; Sallami et al., 2016; Huang et al., 2016; Ali et al., 2016; Kamble and Kumar, 2016; Saikia and Karak, 2016; Zeferino et al., 2016; Pravettoni et al., 2016; Bedon and Amadio, 2016; Mavukkandy et al., 2016; Yeargin et al., 2016; Madani and Dababneh, 2016; Alhasanat et al., 2016; Elliott et al., 2016; Suarez et al., 2016; Kuli et al., 2016; Waters et al., 2016; Montgomery et al., 2016; Lamarre et al., 2016; Daud et al., 2008; Taher et al., 2008; Zulkifli et al., 2008; Pourmahmoud, 2008; Pannirselvam et al., 2008; $\mathrm{Ng}$ et al., 2008; El-Tous, 2008; Akhesmeh et al., 2008; Nachiengtai et al., 2008; Moezi et al., 2008; Boucetta, 2008; Darabi et al., 2008; Semin and Bakar, 2008; Al-Abbas, 2009; Abdullah et al., 2009; Abu-Ein, 2009; Opafunso et al., 2009; Semin et al., 2009a; 2009b; 2009c; Zulkifli et al., 2009; Marzuki et al., 2015; Bier and Mostafavi, 2015; Momta et al., 2015; Farokhi and Gordini, 2015; Khalifa et al., 2015; Yang and Lin, 2015; Demetriou et al., 2015; Rajupillai et al., 2015; Sylvester et al., 2015a; Ab-Rahman et al., 2009; Abdullah and Halim, 2009; Zotos and Costopoulos, 2009; Feraga et al., 2009; Bakar et al., 2009; Cardu et al., 2009; Bolonkin, 2009a; 2009b; Nandhakumar et al., 2009; Odeh et al., 2009; Lubis et al., 2009; Fathallah and Bakar, 2009; Marghany and Hashim, 2009; Kwon et al., 2010; Aly and Abuelnasr, 2010; Farahani et al., 2010;
Ahmed et al., 2010; Kunanoppadon, 2010; Helmy and El-Taweel, 2010; Qutbodin, 2010; Pattanasethanon, 2010; Fen et al., 2011; Thongwan et al., 2011; Theansuwan and Triratanasirichai, 2011; Al Smadi, 2011; Tourab et al., 2011; Raptis et al., 2011; Momani et al., 2011; Ismail et al., 2011; Anizan et al., 2011; Tsolakis and Raptis, 2011; Abdullah et al., 2011; Kechiche et al., 2011; Ho et al., 2011; Rajbhandari et al., 2011; Aleksic and Lovric, 2011; Kaewnai and Wongwises, 2011; Idarwazeh, 2011; Ebrahim et al., 2012; Abdelkrim et al., 2012; Mohan et al., 2012; Abam et al., 2012; Hassan et al., 2012; Jalil and Sampe, 2013; Jaoude and El-Tawil, 2013; Ali and Shumaker, 2013; Zhao, 2013; El-Labban et al., 2013; Djalel et al., 2013; Nahas and Kozaitis, 2014; Petrescu and Petrescu, 2014a; 2014b; 2014c; 2014d; 2014e; 2014f; 2014g; 2014h; 2014i; 2015a; 2015b; 2015c; 2015d; 2015e; 2016a; 2016b; 2016c; 2016d; Fu et al., 2015; AlNasra et al., 2015; Amer et al., 2015; Sylvester et al., 2015b; Kumar et al., 2015; Gupta et al., 2015; Stavridou et al., 2015b; Casadei, 2015; Ge and Xu, 2015; Moretti, 2015; Wang et al., 2015; Petrescu et al., 2017af-aj; 2018o-v; Petrescu, 2015c; 2018a-b; Petrescu and Petrescu, 2018a-b; Petrescu and Petrescu, 2014f; 2014g; 2014h; 2014i).

\section{Materials and Methods}

Such a manipulator that is also a crane can be built even simpler, in various dimensions, depending on where the system will have to work. It can be fully or partially machined, it can be constructed so that it can be manipulated and manually. He will be presented from a constructive, geometrical and kinematic point of view, within the present work, presenting briefly its direct kinematics.

In Fig. 4 is presented such a constructive model capable of moving and transporting various heavy objects through a whole section. The manipulator with three degrees of mobility, can lift a heavy and bulky object and then transport it from one place to another, over short or even greater distances. The man can push a stroller to be fixed such a manipulator with three mobilities. The constructive model presented can be adapted and redesigned in other mechanical variants, the one that will be presented in the paper being only a possible constructive variant. It balances simply, according to the classic balancing model with the companion, generally achieving a static or almost total static balance. In addition, not only does the counterweight mounted on the extension of arm 3 (Fig. 5) help but also the constructive scheme, because a great part of the efforts and even a partial balancing will be supported by the upper-class D coupling of the fourth class, which allows simultaneous rotation. and relative translation of its component elements 3 and 0 (Fig. 5). 


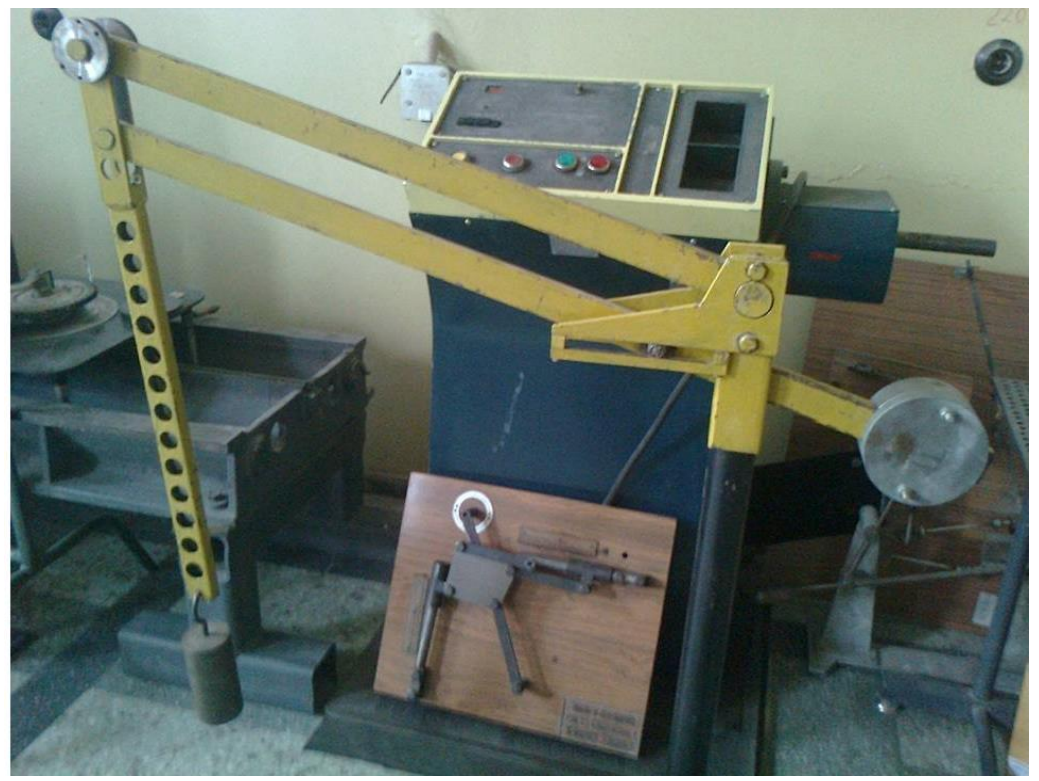

Fig. 4: Constructive scheme of a manipulator with three mobilities

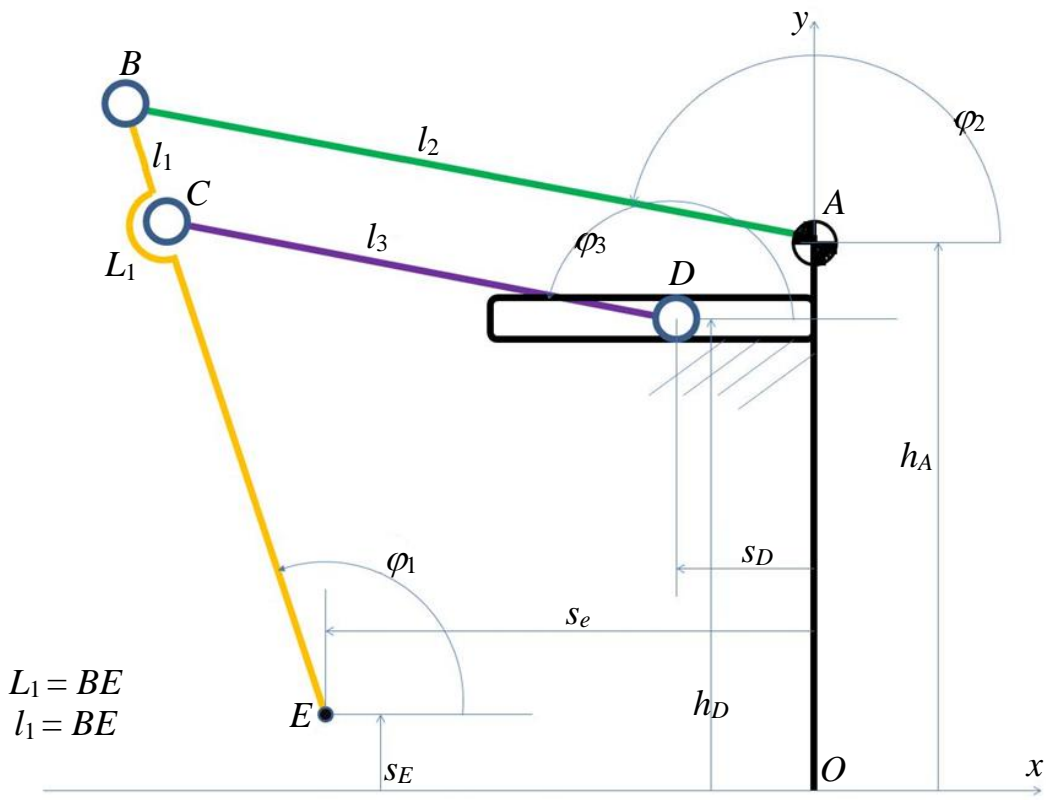

Fig. 5: Kinematic diagram of the planar mechanism $2 \mathrm{R}$ from the component of the $3 \mathrm{R}$ space manipulator

It should also be mentioned that in the direct kinematic study performed in Fig. 5, only three movable elements, 1, 2, 3 and a planning mechanism with two mobilities are considered, in order to simplify the study of the mechanism. In fact, as can be seen from the construction scheme (Fig. 4), the supporting element 0 is also a movable part having a rotation around its own axis, vertically, so that the whole system can be rotated at the desired angle, increasing thus the workspace and transforming the flat movement of the $2 \mathrm{R}$ system into a spatial movement $3 \mathrm{R}$. The rotation can be left to be complete if this is considered necessary.

In the direct kinematics we know, (Give): L1 [m]; L1 [m]; L2 [m]; L3 [m]; hD [m]; harness]; The input parameters are also required: sD [m], FI2 [deg] and four output parameters of the mechanism must be determined kinematically (see kinematic diagram):

FI1 [deg]; Fi3 [deg]; and [m]; se [m], for both possible variants I and II. It must be specified that the 
mechanism can be positioned in two different ways when setting the input parameters so that at the output we will have one of the two real working situations, both variants (I and II) can be determined with the computation relays. lower:

$$
\left\{\begin{array}{l}
\text { Version } \quad I \text { with }- \\
A=\left(l_{2} \cdot \cos \varphi_{2}-s_{D}\right)^{2}+\left(h_{A}-h_{D}+l_{2} \cdot \sin \varphi_{2}\right)^{2}+l_{1}^{2}-l_{3}^{2} \\
B=-2 \cdot l_{1} \cdot\left(l_{2} \cdot \cos \varphi_{2}-s_{D}\right) \\
C=2 \cdot l_{1} \cdot\left(h_{A}-h_{D}+l_{2} \cdot \sin \varphi_{2}\right) \\
\cos \varphi_{1}=\frac{-A \cdot B-C \cdot \sqrt{B^{2}+C^{2}-A^{2}}}{B^{2}+C^{2}} \\
\Rightarrow \varphi_{1}=\arccos \left(\cos \varphi_{1}\right) \\
\cos \varphi_{3}=\frac{l_{2} \cdot \cos \varphi_{2}-l_{1} \cdot \cos \varphi_{1}-s_{D}}{l_{3}} \\
\sin \varphi_{3}=\frac{l_{2} \cdot \sin \varphi_{2}-l_{1} \cdot \sin \varphi_{1}+h_{A}-h_{D}}{l_{3}} \\
\varphi_{3}=\operatorname{semn}\left(\sin \varphi_{3}\right) \cdot \arccos \left(\cos \varphi_{3}\right) \\
s_{E}=h_{A}+l_{2} \cdot \sin \varphi_{2}-L_{1} \cdot \sin \varphi_{1} \\
s_{e}=l_{2} \cdot \cos \varphi_{2}-L_{1} \cdot \cos \varphi_{1}
\end{array}\right.
$$

$$
\left\{\begin{array}{l}
\text { Version II with }+ \\
A=\left(l_{2} \cdot \cos \varphi_{2}-s_{D}\right)^{2}+\left(h_{A}-h_{D}+l_{2} \cdot \sin \varphi_{2}\right)^{2}+l_{1}^{2}-l_{3}^{2} \\
B=-2 \cdot l_{1} \cdot\left(l_{2} \cdot \cos \varphi_{2}-s_{D}\right) \\
C=2 \cdot l_{1} \cdot\left(h_{A}-h_{D}+l_{2} \cdot \sin \varphi_{2}\right) \\
\cos \varphi_{1}=\frac{-A \cdot B+C \cdot \sqrt{B^{2}+C^{2}-A^{2}}}{B^{2}+C^{2}} \Rightarrow \\
\Rightarrow \varphi_{1}=\arccos \left(\cos \varphi_{1}\right) \\
\cos \varphi_{3}=\frac{l_{2} \cdot \cos \varphi_{2}-l_{1} \cdot \cos \varphi_{1}-s_{D}}{l_{3}} \\
\sin \varphi_{3}=\frac{l_{2} \cdot \sin \varphi_{2}-l_{1} \cdot \sin \varphi_{1}+h_{A}-h_{D}}{l_{3}} \\
\varphi_{3}=\operatorname{semn}\left(\sin \varphi_{3}\right) \cdot \arccos \left(\cos \varphi_{3}\right) \\
s_{E}=h_{A}+l_{2} \cdot \sin \varphi_{2}-L_{1} \cdot \sin \varphi_{1} \\
s_{e}=l_{2} \cdot \cos \varphi_{2}-L_{1} \cdot \cos \varphi_{1}
\end{array}\right.
$$

\section{Result and Discussion}

In a calculation example, in the diagram in Fig. 6 (for version I) and Fig. 7 (for version II) one can observe the output values of the angles FI1 and FI3, depending on the value imposed at the input of the angle FI2 on the abscissa.

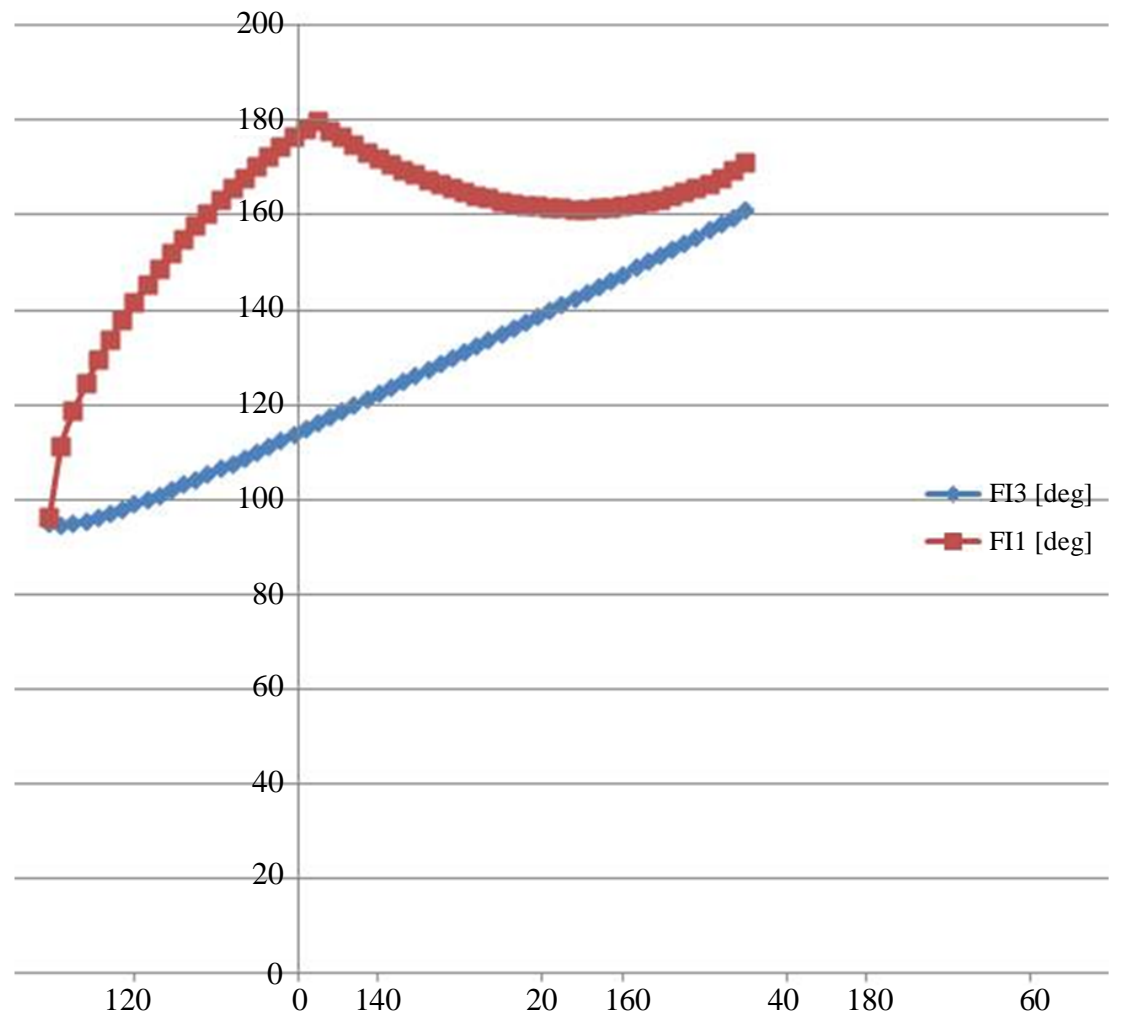

Fig. 6: Output values of the angles FI1 and FI3, depending on the value imposed at the input of the angle FI2 on the abscissa, for version I 
Relly Victoria Virgil Petrescu / Journal of Mechatronics and Robotics 2020, Volume 4: 85.105

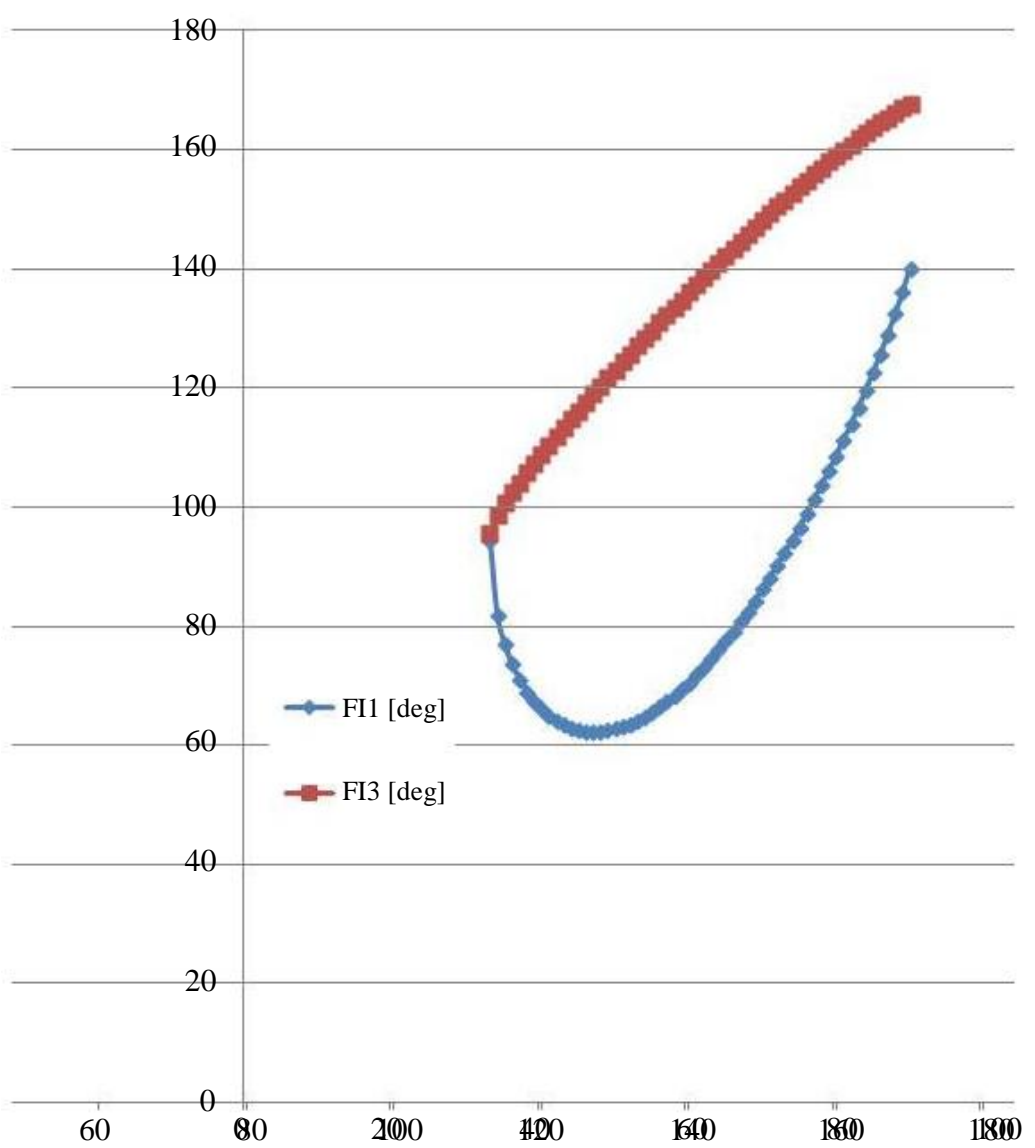

Fig. 7: Output values of the angles FI1 and FI3, depending on the value imposed at the input of the angle FI2 on the abscissa, for version I

$$
\text { FI2 [deg] }
$$

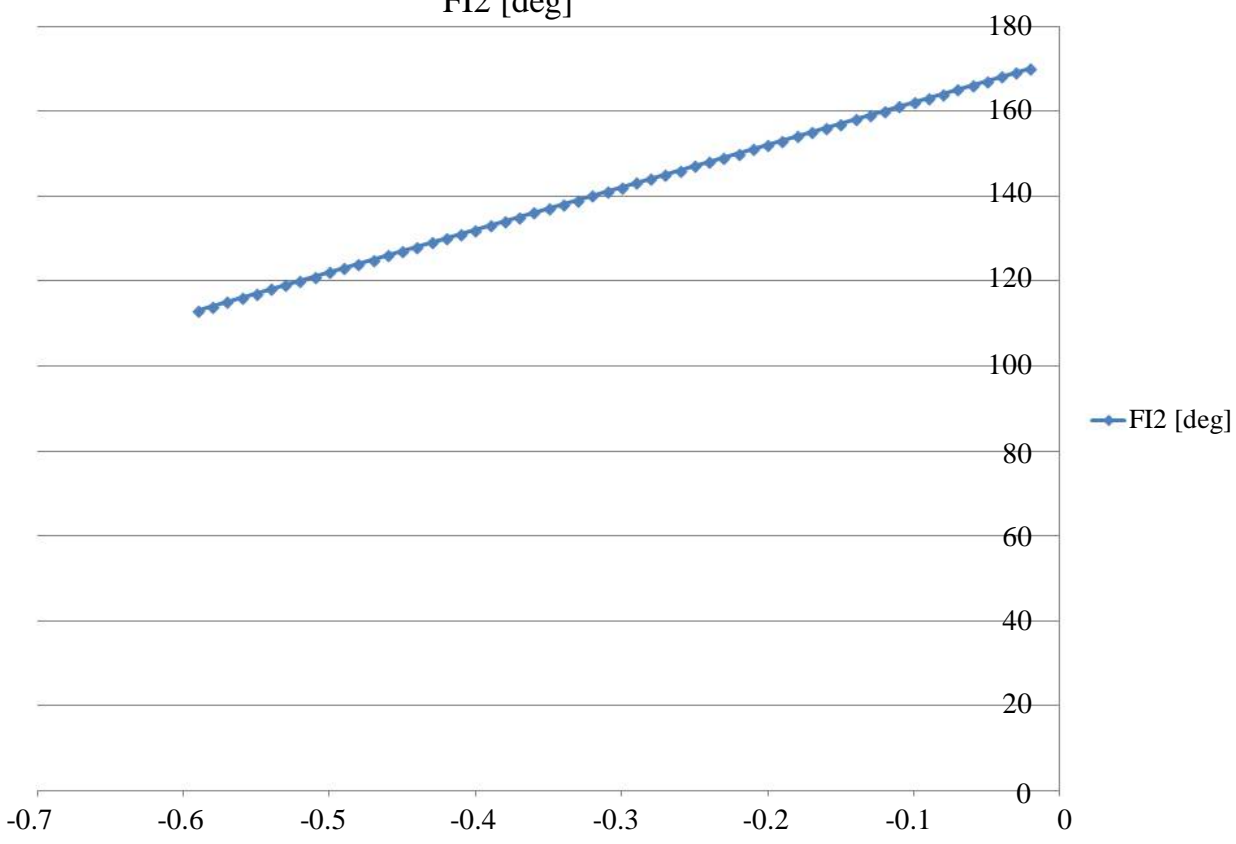

Fig. 8: The values of sD [m] corresponding to the angle FI2 [deg] 
Table 1: The values used for the lengths in the calculation example

\begin{tabular}{ll}
\hline $\mathrm{L} 1[\mathrm{~m}]$ & 2 \\
\hline $11[\mathrm{~m}]$ & 0.25 \\
$12[\mathrm{~m}]$ & 2 \\
$13[\mathrm{~m}]$ & 1.8 \\
$\mathrm{hD}[\mathrm{m}]$ & 2.3 \\
$\mathrm{hA}[\mathrm{m}]$ & 2.5 \\
\hline
\end{tabular}

The variation of FI3 is represented by blue and the angle of FI1 with red. The values used for the lengths in the calculation example are given in Table 1.

The values of $\mathrm{sD}[\mathrm{m}]$ corresponding to the angle FI2 [deg] of input are collected from the graph shown in Fig. 8.

\section{Conclusion}

In the industrial halls it is often necessary to handle large objects, with a large and large table, which have to be transported not over long distances but moved from one place to another, raised, then lowered to various levels, left or right. Such repeated manipulations of heavy and dangerous objects can be done only with the help of a manipulator, which can be a crane, a specially designed trolley, a complicated robot or a simple manipulator as is the case for the one presented in the paper.

The paper briefly presents the kinematic study of a manipulator with three mobilities, which can be used both in industrial halls and in garages, depending on its suitably chosen constructive size, which at smaller dimensions can be handled very easily. This manipulator can carry large loads, thus easing the work of the human being and preventing it from major dangers that can occur during the transport of large pieces and a large mass.

\section{Acknowledgement}

This text was acknowledged and appreciated by Dr. Veturia CHIROIU Honorific member of Technical Sciences Academy of Romania (ASTR) PhD supervisor in Mechanical Engineering.

\section{Funding Information}

Research contract:

- 1-Research contract: Contract number 36-5-4D/1986 from 24IV1985, beneficiary CNST RO (Romanian National Center for Science and Technology) Improving dynamic mechanisms

- 2-Contract research integration. 19-91-3 from 29.03.1991; Beneficiary: MIS; TOPIC: Research on designing mechanisms with bars, cams and gears, with application in industrial robots
- 3-Contract research. GR 69/10.05.2007: NURC in 2762; theme 8: Dynamic analysis of mechanisms and manipulators with bars and gears

- 4-Labor contract, no. 35/22.01.2013, the UPB, "Stand for reading performance parameters of kinematics and dynamic mechanisms, using inductive and incremental encoders, to a Mitsubishi Mechatronic System" "PN-II-IN-CI-2012-1-0389"

All these matters are copyrighted! Copyrights: 394qodGnhhtej, from 17-02-2010 13:42:18; 463vpstuCGsiy, from 20-03-2010 12:45:30; 631sqfsgqvutm, from 24-05-2010 16:15:22; 933 CrDztEfqow, from 07-01-2011 13:37:52.

\section{Ethics}

This article is original and contains unpublished material. Authors declare that are not ethical issues and no conflict of interest that may arise after the publication of this manuscript.

\section{References}

Aabadi, M.M.L., 2019. Dynamic reliability analysis of steel moment frames using Monte Carlo technique. Am. J. Eng. Applied Sci., 12: 204-213.

DOI: 10.3844/ajeassp.2019.204.213

Ab-Rahman, M.S., H. Guna, M.H. Harun, S.D. Zan and K. Jumari, 2009. Cost-effective fabrication of selfmade $1 \times 12$ polymer optical fiber-based optical splitters for automotive application. Am. J. Eng. Applied Sci., 2: 252-259.

DOI: 10.3844/ajeassp.2009.252.259

Abam, F.I., I.U. Ugot and D.I. Igbong, 2012. Performance analysis and components irreversibilities of a $(25 \mathrm{MW})$ gas turbine power plant modeled with a spray cooler. Am. J. Eng. Applied Sci., 5: 35-41.

DOI: 10.3844/ajeassp.2012.35.41

Abdelkrim, H., S.B. Othman, A.K.B. Salem and S.B. Saoud, 2012. Dynamic partial reconfiguration contribution on system on programmable chip architecture for motor drive implementation. Am. J. Eng. Applied Sci., 5: 15-24.

DOI: 10.3844/ajeassp.2012.15.24

Abdullah, M.Z., A. Saat and Z. Hamzah, 2011. Optimization of energy dispersive $\mathrm{x}$-ray fluorescence spectrometer to analyze heavy metals in moss samples. Am. J. Eng. Applied Sci., 4: 355-362. DOI: 10.3844/ajeassp.2011.355.362

Abdullah, M., A.F.M. Zain, Y.H. Ho and S. Abdullah, 2009. TEC and scintillation study of equatorial ionosphere: A month campaign over sipitang and parit raja stations, Malaysia. Am. J. Eng. Applied Sci., 2: 44-49. DOI: 10.3844/ajeassp.2009.44.49 
Abdullah, H. and S.A. Halim, 2009. Electrical and magnetoresistive studies $\mathrm{Nd}$ doped on La-Ba-Mn- $\mathrm{O}_{3}$ manganites for low-field sensor application. Am. J. Eng. Applied Sci., 2: 297-303.

DOI: 10.3844/ajeassp.2009.297.303

Abouobaida, H., 2016. Robust and efficient controller to design a standalone source supplied DC and AC load powered by photovoltaic generator. Am. J. Eng. Applied Sci., 9: 894-901.

DOI: 10.3844/ajeassp.2016.894.901

Abu-Ein, S., 2009. Numerical and analytical study of exhaust gases flow in porous media with applications to diesel particulate filters. Am. J. Eng. Applied Sci., 2: 70-75.

DOI: 10.3844/ajeassp.2009.70.75

Abu-Lebdeh, M., G. Pérez-de León, S.A. Hamoush, R.D. Seals and V.E. Lamberti, 2016. Gas atomization of molten metal: Part II. Applications. Am. J. Eng. Applied Sci., 9: 334-349.

DOI: 10.3844/ajeassp.2016.334.349

Agarwala, S., 2016. A perspective on 3D bioprinting technology: Present and future. Am. J. Eng. Applied Sci., 9: 985-990.

DOI: 10.3844/ajeassp.2016.985.990

Ahmed, M., R. Khan, M. Billah and S. Farhana, 2010. A novel navigation algorithm for hexagonal hexapod robot. Am. J. Eng. Applied Sci., 3: 320-327. DOI: 10.3844/ajeassp.2010.320.327

Ahmed, M.K., H. Haque and H. Rahman, 2016. An approach to develop a dynamic job shop scheduling by fuzzy rule-based system and comparative study with the traditional priority rules. Am. J. Eng. Applied Sci., 9: 202-212.

DOI: 10.3844/ajeassp.2016.202.212

Akhesmeh, S., N. Pourmahmoud and H. Sedgi, 2008. Numerical study of the temperature separation in the ranque-hilsch vortex tube. Am. J. Eng. Applied Sci., 1: 181-187. DOI: 10.3844/ajeassp.2008.181.187

Al-Abbas, I.K., 2009. Reduced order models of a current source inverter induction motor drive. Am. J. Eng. Applied Sci., 2: 39-43.

DOI: 10.3844/ajeassp.2009.39.43

Al-Hasan and A.S. Al-Ghamdi, 2016. Energy balance for a diesel engine operates on a pure biodiesel, diesel fuel and biodiesel-diesel blends. Am. J. Eng. Applied Sci., 9: 458-465.

DOI: 10.3844/ajeassp.2016.458.465

Al Smadi, T.A., 2011. Low cost smart sensor design. Am. J. Eng. Applied Sci., 4: 162-168.

DOI: 10.3844/ajeassp.2011.162.168

Al Qadi, A.N.S., M.B.A. ALhasanat, A. Al Dahamsheh and S. Al Zaiydneen, 2016a. Using of box-benken method to predict the compressive strength of selfcompacting concrete containing Wadi Musa bentonite, Jordan. Am. J. Eng. Applied Sci., 9: 406-411. DOI: 10.3844/ajeassp.2016.406.411
Al Qadi, A.N.S., M.B.A. Alhasanat and M. Haddad, 2016b. Effect of crumb rubber as coarse and fine aggregates on the properties of asphalt concrete. Am. J. Eng. Applied Sci., 9: 558-564. DOI: 10.3844/ajeassp.2016.558.564

Aleksic, S. and A. Lovric, 2011. Energy consumption and environmental implications of wired access networks. Am. J. Eng. Applied Sci., 4: 531-539. DOI: 10.3844/ajeassp.2011.531.539

Alhasanat, M.B., A.N. Al Qadi, O.A. Al Khashman and A. Dahamsheh, 2016. Scanning electron microscopic evaluation of self-compacting concrete spalling at elevated temperatures. Am. J. Eng. Applied Sci., 9: 119-127.

DOI: 10.3844/ajeassp.2016.119.127

Ali, K.S. and J.L. Shumaker, 2013. Hardware in the loop simulator for multi-agent unmanned aerial vehicles environment. Am. J. Eng. Applied Sci., 6: 172-177. DOI: 10.3844/ajeassp.2013.172.177

Ali, G.A.M., O. Fouad and S.A. Makhlouf, 2016. Electrical properties of cobalt oxide/silica nanocomposites obtained by sol-gel technique. Am. J. Eng. Applied Sci., 9: 12-16.

DOI: 10.3844/ajeassp.2016.12.16

Al-Nasra, M. Daoudb and T.M. Abu-Lebdeh, 2015. The use of the super absorbent polymer as water blocker in concrete structures. Am. J. Eng. Applied Sci., 8: 659-665. DOI: 10.3844/ajeassp.2015.659.665

Alwetaishi, M.S., 2016. Impact of building function on thermal comfort: A review paper. Am. J. Eng. Applied Sci., 9: 928-945.

DOI: 10.3844/ajeassp.2016.928.945

Aly, W.M. and M.S. Abuelnasr, 2010. Electronic design automation using object oriented electronics. Am. J. Eng. Applied Sci., 3: 121-127.

DOI: 10.3844/ajeassp.2010.121.127

Amani, N., 2016. Design and implementation of optimum management system using cost evaluation and financial analysis for prevention of building failure. Am. J. Eng. Applied Sci., 9: 281-296.

DOI: 10.3844/ajeassp.2016.281.296

Amer, S., S. Hamoush and T.M. Abu-Lebdeh, 2015. Experimental evaluation of the raking energy in damping system of steel stud partition walls. Am. J. Eng. Applied Sci., 8: 666-677. DOI: 10.3844/ajeassp.2015.666.677

Anizan, S., K. Yusri, C.S. Leong, N. Amin and S. Zaidi et al., 2011. Effects of the contact resistivity variations of the screen-printed silicon solar cell. Am. J. Eng. Applied Sci., 4: 328-331. DOI: 10.3844 /ajeassp.2011.328.331

Antonescu, P. and F. Petrescu, 1985. An analytical method of synthesis of cam mechanism and flat stick. Proceedings of the 4th International Symposium on Theory and Practice of Mechanisms, (TPM’ 89), Bucharest. 
Antonescu, P. and F. Petrescu, 1989. Contributions to kinetoplast dynamic analysis of distribution mechanisms. Bucharest.

Antonescu, P., M. Oprean and F. Petrescu, 1985a. Contributions to the synthesis of oscillating cam mechanism and oscillating flat stick. Proceedings of the 4th International Symposium on Theory and Practice of Mechanisms, (TPM' 85), Bucharest.

Antonescu, P., M. Oprean and F. Petrescu, 1985b. At the projection of the oscillate cams, there are mechanisms and distribution variables. Proceedings of the 5th Conference of Engines, Automobiles, Tractors and Agricultural Machines, (TAM' 58), IMotors and Cars, Brasov.

Antonescu, P., M. Oprean and F. Petrescu, 1986. Projection of the profile of the rotating camshaft acting on the oscillating plate with disengagement. Proceedings of the 3rd National Computer-aided Design Symposium in the field of Mechanisms and Machine Parts, (MMP' 86), Brasov.

Antonescu, P., M. Oprean and F. Petrescu, 1987. Dynamic analysis of the cam distribution mechanisms. Proceedings of the 7th National Symposium on Industrial Robots and Space Mechanisms, (RSM' 87), Bucharest.

Antonescu, P., M. Oprean and F. Petrescu, 1988. Analytical synthesis of Kurz profile, rotating the flat cam. Mach. Build. Rev.

Antonescu, P., F. Petrescu and O. Antonescu, 1994. Contributions to the synthesis of the rotating cam mechanism and the tip of the balancing tip. Brasov.

Antonescu, P., F. Petrescu and D. Antonescu, 1997. Geometrical synthesis of the rotary cam and balance tappet mechanism. Bucharest, 3: 23-23.

Antonescu, P., F. Petrescu and O. Antonescu, 2000a. Contributions to the synthesis of the rotary disc-cam profile. Proceedings of the 8th International Conference on the Theory of Machines and Mechanisms, (TMM' 00), Liberec, Czech Republic, pp: 51-56.

Antonescu, P., F. Petrescu and O. Antonescu, 2000b. Synthesis of the rotary cam profile with balance follower. Proceedings of the 8th Symposium on Mechanisms and Mechanical Transmissions, (MMT' 00), Timişoara, pp: 39-44.

Antonescu, P., F. Petrescu and O. Antonescu, 2001. Contributions to the synthesis of mechanisms with rotary disc-cam. Proceedings of the 8th IFToMM International Symposium on Theory of Machines and Mechanisms, (TMM' 01), Bucharest, ROMANIA, pp: 31-36.
Ascione, F., N. Bianco, R.F. De Masi, F. de Rossi and C. De Stasio et al., 2016. Energy audit of health care facilities: dynamic simulation of energy performances and energy-oriented refurbishment of system and equipment for microclimatic control. Am. J. Eng. Applied Sci., 9: 814-834.

DOI: 10.3844/ajeassp.2016.814.834

Augustine, A., R.D. Prakash, R. Xavier and M.C. Parassery, 2016. Review of signal processing techniques for detection of power quality events. Am. J. Eng. Applied Sci., 9: 364-370.

DOI: 10.3844/ajeassp.2016.364.370

Aversa, R., R.V.V. Petrescu, A. Apicella and F.I.T. Petrescu, 2017a. Nano-diamond hybrid materials for structural biomedical application. Am. J. Biochem. Biotechnol., 13: 34-41.

DOI: 10.3844/ajbbsp.2017.34.41

Aversa, R., R.V. Petrescu, B. Akash, R.B. Bucinell and J.M. Corchado et al., 2017b. Kinematics and forces to a new model forging manipulator. Am. J. Applied Sci., 14: 60-80. DOI: 10.3844/ajassp.2017.60.80

Aversa, R., R.V. Petrescu, A. Apicella, F.I.T. Petrescu and J.K. Calautit et al., 2017c. Something about the $\mathrm{V}$ engines design. Am. J. Applied Sci., 14: 34-52. DOI: 10.3844/ajassp.2017.34.52

Aversa, R., D. Parcesepe, R.V.V. Petrescu, F. Berto and G. Chen et al., 2017d. Process ability of bulk metallic glasses. Am. J. Applied Sci., 14: 294-301. DOI: 10.3844/ajassp.2017.294.301

Aversa, R., R.V.V. Petrescu, B. Akash, R.B. Bucinell and J.M. Corchado et al., 2017e. Something about the balancing of thermal motors. Am. J. Eng. Applied Sci., 10: 200.217.

DOI: 10.3844/ajeassp.2017.200.217

Aversa, R., F.I.T. Petrescu, R.V. Petrescu and A. Apicella, 2016a. Biomimetic FEA bone modeling for customized hybrid biological prostheses development. Am. J. Applied Sci., 13: 1060-1067. DOI: 10.3844/ajassp.2016.1060.1067

Aversa, R., D. Parcesepe, R.V. Petrescu, G. Chen and F.I.T. Petrescu et al., 2016b. Glassy amorphous metal injection molded induced morphological defects. Am. J. Applied Sci., 13: 1476-1482. DOI: 10.3844/ajassp.2016.1476.1482

Aversa, R., R.V. Petrescu, F.I.T. Petrescu and A. Apicella, 2016c. Smart-factory: Optimization and process control of composite centrifuged pipes. Am. J. Applied Sci., 13: 1330-1341.

DOI: 10.3844/ajassp.2016.1330.1341

Aversa, R., F. Tamburrino, R.V. Petrescu, F.I.T. Petrescu and M. Artur et al., 2016d. Biomechanically inspired shape memory effect machines driven by muscle like acting NiTi alloys. Am. J. Applied Sci., 13: 1264-1271.

DOI: 10.3844/ajassp.2016.1264.1271 
Aversa, R., E.M. Buzea, R.V. Petrescu, A. Apicella and M. Neacsa et al., 2016e. Present a mechatronic system having able to determine the concentration of carotenoids. Am. J. Eng. Applied Sci., 9: 1106-1111.

DOI: 10.3844/ajeassp.2016.1106.1111

Aversa, R., R.V. Petrescu, R. Sorrentino, F.I.T. Petrescu and A. Apicella, 2016f. Hybrid ceramopolymeric nanocomposite for biomimetic scaffolds design and preparation. Am. J. Eng. Applied Sci., 9: 1096-1105.

DOI: 10.3844/ajeassp.2016.1096.1105

Aversa, R., V. Perrotta, R.V. Petrescu, C. Misiano and F.I.T. Petrescu et al., 2016g. From structural colors to super-hydrophobicity and achromatic transparent protective coatings: Ion plating plasma assisted $\mathrm{TiO}_{2}$ and $\mathrm{SiO}_{2}$ nano-film deposition. Am. J. Eng. Applied Sci., 9: 1037-1045.

DOI: 10.3844/ajeassp.2016.1037.1045

Aversa, R., R.V. Petrescu, F.I.T. Petrescu and A. Apicella, 2016h. Biomimetic and evolutionary design driven innovation in sustainable products development. Am. J. Eng. Applied Sci., 9: 1027-1036. DOI: 10.3844/ajeassp.2016.1027.1036

Aversa, R., R.V. Petrescu, A. Apicella and F.I.T. Petrescu, 2016i. Mitochondria are naturally micro robots - a review. Am. J. Eng. Applied Sci., 9: 991-1002. DOI: 10.3844/ajeassp.2016.991.1002

Aversa, R., R.V. Petrescu, A. Apicella and F.I.T. Petrescu, 2016j. We are addicted to vitamins $\mathrm{C}$ and E-A review. Am. J. Eng. Applied Sci., 9: 1003-1018. DOI: 10.3844/ajeassp.2016.1003.1018

Aversa, R., R.V. Petrescu, A. Apicella and F.I.T. Petrescu, 2016k. Physiologic human fluids and swelling behavior of hydrophilic biocompatible hybrid ceramo-polymeric materials. Am. J. Eng. Applied Sci., 9: 962-972.

DOI: 10.3844/ajeassp.2016.962.972

Aversa, R., R.V. Petrescu, A. Apicella and F.I.T. Petrescu, 20161. One can slow down the aging through antioxidants. Am. J. Eng. Applied Sci., 9: 1112-1126. DOI: 10.3844/ajeassp.2016.1112.1126

Aversa, R., R.V. Petrescu, A. Apicella and F.I.T. Petrescu, 2016m. About homeopathy or «Similia Similibus Curentur 》. Am. J. Eng. Applied Sci., 9: 1164-1172.

DOI: 10.3844/ajeassp.2016.1164.1172

Aversa, R., R.V. Petrescu, A. Apicella and F.I.T. Petrescu, 2016n. The basic elements of life's. Am. J. Eng. Applied Sci., 9: 1189-1197.

DOI: 10.3844/ajeassp.2016.1189.1197

Aversa, R., F.I.T. Petrescu, R.V. Petrescu and A. Apicella, 2016o. Flexible stem trabecular prostheses. Am. J. Eng. Applied Sci., 9: 1213-1221. DOI: 10.3844/ajeassp.2016.1213.122
Babayemi, A.K., 2016. Thermodynamics, non-linear isotherms, statistical modeling and optimization of phosphorus adsorption from wastewater. Am. J. Eng. Applied Sci., 9: 1019-1026.

DOI: 10.3844/ajeassp.2016.1019.1026

Bakar, R.A., M.K. Mohammed and M.M. Rahman, 2009. Numerical study on the performance characteristics of hydrogen fueled port injection internal combustion engine. Am. J. Eng. Applied Sci., 2: 407-415.

DOI: 10.3844/ajeassp.2009.407.415

Barone, G., A. Buonomano, C. Forzano and A. Palombo, 2016. WLHP systems in commercial buildings: A case study analysis based on a dynamic simulation approach. Am. J. Eng. Applied Sci., 9: 659-668. DOI: 10.3844/ajeassp.2016.659.668

Bedon, C., 2016. Review on the use of FRP composites for facades and building skins. Am. J. Eng. Applied Sci., 9: 713-723.

DOI: $10.3844 /$ ajeassp.2016.713.723

Bedon, C. and C. Amadio, 2016. A unified approach for the shear buckling design of structural glass walls with non-ideal restraints. Am. J. Eng. Applied Sci., 9: 64-78. DOI: 10.3844/ajeassp.2016.64.78

Bedon, C. and C. Louter, 2016. Finite-element numerical simulation of the bending performance of posttensioned structural glass beams with adhesively bonded CFRP tendons. Am. J. Eng. Applied Sci., 9: 680-691. DOI: 10.3844/ajeassp.2016.680.691

Ben-Faress, M., A. Elouadi and D. Gretete, 2019. Global supply chain risk management. Am. J. Eng. Applied Sci., 12: 147-155.

DOI: 10.3844/ajeassp.2019.147.155

Bier, H. and S. Mostafavi, 2015. Structural optimization for materially informed design to robotic production processes. Am. J. Eng. Applied Sci., 8: 549-555. DOI: 10.3844/ajeassp.2015.549.555

Bolonkin, A., 2009a. Femtotechnology: Nuclear matter with fantastic properties. Am. J. Eng. Applied Sci., 2: 501-514. DOI: 10.3844/ajeassp.2009.501.514

Bolonkin, A., 2009b. Converting of matter to nuclear energy by ab-generator. Am. J. Eng. Applied Sci., 2: 683-693. DOI: 10.3844/ajeassp.2009.683.693

Boucetta, A., 2008. Vector control of a variable reluctance machine stator and rotor discs imbricates. Am. J. Eng. Applied Sci., 1: 260-265. DOI: 10.3844/ajeassp.2008.260.265

Bourahla, N. and A. Blakeborough, 2015. Similitude distortion compensation for a small scale model of a knee braced steel frame. Am. J. Eng. Applied Sci., 8: 481-488. DOI: 10.3844/ajeassp.2015.481.488

Bucinell, R.B., 2016. Stochastic model for variable amplitude fatigue induced delamination growth in graphite/epoxy laminates. Am. J. Eng. Applied Sci., 9: 635-646. DOI: 10.3844/ajeassp.2016.635.646 
Budak, S., Z. Xiao, B. Johnson, J. Cole and M. Drabo et al., 2016. Highly-efficient advanced thermoelectric devices from different multilayer thin films. Am. J. Eng. Applied Sci., 9: 356-363.

DOI: 10.3844/ajeassp.2016.356.363

Buonomano, A., F. Calise and M. Vicidomini, 2016a. A novel prototype of a small-scale solar power plant: Dynamic simulation and thermoeconomic analysis. Am. J. Eng. Applied Sci., 9: 770-788.

DOI: 10.3844/ajeassp.2016.770.788

Buonomano, A., F. Calise, M.D. d'Accadia, R. Vanoli and M. Vicidomini, 2016b. Simulation and experimental analysis of a demonstrative solar heating and cooling plant installed in Naples (Italy). Am. J. Eng. Applied Sci., 9: 798-813.

DOI: 10.3844/ajeassp.2016.798.813

Cao, W., H. Ding, Z. Bin and C. Ziming, 2013. New structural representation and digital-analysis platform for symmetrical parallel mechanisms. Int. J. Adv. Robotic Sys. DOI: 10.5772/56380

Calise, F., M.D. dâ' Accadia, L. Libertini, E. Quiriti and M. Vicidomini, 2016. Dynamic simulation and optimum operation strategy of a trigeneration system serving a hospital. Am. J. Eng. Applied Sci., 9: 854-867.

DOI: 10.3844/ajeassp.2016.854.867

Campo, T., M. Cotto, F. Marquez, E. Elizalde and C. Morant, 2016. Graphene synthesis by plasmaenhanced CVD growth with ethanol. Am. J. Eng. Applied Sci., 9: 574-583. DOI: 10.3844/ajeassp.2016.574.583

Cardu, M., P. Oreste and T. Cicala, 2009. Analysis of the tunnel boring machine advancement on the Bologna-Florence railway link. Am. J. Eng. Applied Sci., 2: 416-420.

DOI: 10.3844/ajeassp.2009.416.420

Casadei, D., 2015. Bayesian statistical inference for number counting experiments. Am. J. Eng. Applied Sci., 8: 730-735.

DOI: 10.3844/ajeassp.2015.730.735

Comanescu, A., 2010. Bazele Modelarii Mecanismelor. 1st Edn., E. Politeh, Press, Bucureşti, pp: 274.

Darabi, A., S.A. Soleamani and A. Hassannia, 2008. Fuzzy based digital automatic voltage regulator of a synchronous generator with unbalanced loads. Am. J. Eng. Applied Sci., 1: 280-286.

DOI: 10.3844/ajeassp.2008.280.286

Daud, H., N. Yahya, A.A. Aziz and M.F. Jusoh, 2008. Development of wireless electric concept powering electrical appliances. Am. J. Eng. Applied Sci., 1: 12-15. DOI: 10.3844/ajeassp.2008.12.15

De León, J., M.D.C. Cotto and F. Márquez, 2019. Toxicology of nanomaterials on zebrafish. Am. J. Eng. Applied Sci., 12: 193-203.

DOI: 10.3844/ajeassp.2019.193.203
Demetriou, D., N. Nikitas and K.D. Tsavdaridis, 2015. Semi active tuned mass dampers of buildings: A simple control option. Am. J. Eng. Applied Sci., 8: 620-632. DOI: 10.3844/ajeassp.2015.620.632

Dixit, S. and S. Pal, 2015. Synthesis and characterization of ink (Carbon)-perovskite/polyaniline ternary composite electrode for sodium chloride separation. Am. J. Eng. Applied Sci., 8: 527-537. DOI: 10.3844/ajeassp.2015.527.537

Djalel, D., M. Mourad and H. Labar, 2013. New approach of electromagnetic fields of the lightning discharge. Am. J. Eng. Applied Sci., 6: 369-383. DOI: 10.3844/ajeassp.2013.369.383

Dong, H., N. Giakoumidis, N. Figueroa and N. Mavridis, 2013. Approaching behaviour monitor and vibration indication in developing a General Moving Object Alarm System (GMOAS). Int. J. Adv. Robotic Sys. DOI: $10.5772 / 56586$

Ebrahim, N.A., S. Ahmed, S.H.A. Rashid and Z. Taha, 2012. Technology use in the virtual R\&D teams. Am. J. Eng. Applied Sci., 5: 9-14. DOI: 10.3844/ajeassp.2012.9.14

El-Labban, H.F., M. Abdelaziz and E.R.I. Mahmoud, 2013. Modification of carbon steel by laser surface melting: Part I: Effect of laser beam travelling speed on microstructural features and surface hardness. Am. J. Eng. Applied Sci., 6: 352-359. DOI: 10.3844/ajeassp.2013.352.359

Elliott, A., S. AlSalihi, A.L. Merriman and M.M. Basti, 2016. Infiltration of nanoparticles into porous binder jet printed parts. Am. J. Eng. Applied Sci., 9: 128-133. DOI: 10.3844/ajeassp.2016.128.133

Elmeddahi, Y., H. Mahmoudi, A. Issaadi, M.F.A. Goosen and R. Ragab, 2016. Evaluating the effects of climate change and variability on water resources: A case study of the Cheliff Basin in Algeria. Am. J. Eng. Applied Sci., 9: 835-845. DOI: 10.3844/ajeassp.2016.835.845

El-Tous, Y., 2008. Pitch angle control of variable speed wind turbine. Am. J. Eng. Applied Sci., 1: 118-120. DOI: 10.3844/ajeassp.2008.118.120

Faizal, A., S. Mulyono, R. Yendra and A. Fudholi, 2016. Design Maximum Power Point Tracking (MPPT) on photovoltaic panels using fuzzy logic method. Am. J. Eng. Applied Sci., 9: 789-797. DOI: 10.3844/ajeassp.2016.789.797

Farahani, A.S., N.M. Adam and M.K.A. Ariffin, 2010. Simulation of airflow and aerodynamic forces acting on a rotating turbine ventilator. Am. J. Eng. Applied Sci., 3: 159-170.

DOI: 10.3844/ajeassp.2010.159.170

Farokhi, E. and M. Gordini, 2015. Investigating the parameters influencing the behavior of knee braced steel structures. Am. J. Eng. Applied Sci., 8: 567-574. DOI: 10.3844/ajeassp.2015.567.574 
Fathallah, A.Z.M. and R.A. Bakar, 2009. Prediction studies for the performance of a single cylinder high speed spark ignition linier engine with spring mechanism as return cycle. Am. J. Eng. Applied Sci., 2: 713-720.

DOI: 10.3844/ajeassp.2009.713.720

Fen, Y.W., W.M.M. Yunus, M.M. Moksin, Z.A. Talib and N.A. Yusof, 2011. Optical properties of crosslinked chitosan thin film with glutaraldehyde using surface plasmon resonance technique. Am. J. Eng. Applied Sci., 4: 61-65.

DOI: 10.3844/ajeassp.2011.61.65

Feraga, C.E., A. Moussaoui, A. Bouldjedri and A. Yousfi, 2009. Robust position controller for a permanent magnet synchronous actuator. Am. J. Eng. Applied Sci., 2: 388-392.

DOI: 10.3844/ajeassp.2009.388.392

Fontánez, K., A. García, M.D.C. Cotto-Maldonado, J. Duconge and C. Morant et al., 2019. Development of Ionizing Radiation Sensors Based on Carbon Nanotubes. Am. J. Eng. Applied Sci., 12: 185-192. DOI: 10.3844/ajeassp.2019.185.192

Franklin, D.J., 1930. Ingenious Mechanisms for Designers and Inventors. 1st Edn., Industrial Press Publisher.

Fu, Y.F., J. Gong, H. Huang, Y.J. Liu and D. Zhu et al., 2015. Parameters optimization of adaptive cashew shelling cutter based on BP neural network and genetic algorithm. Am. J. Eng. Applied Sci., 8: 648-658. DOI: 10.3844/ajeassp.2015.648.658

Ge, L. and X. Xu, 2015. A scheme design of cloud + end technology in demand side management. Am. J. Eng. Applied Sci., 8: 736-747.

DOI: 10.3844/ajeassp.2015.736.747

Gupta, P., A. Gupta and A. Asati, 2015. Ultra low power MUX based compressors for wallace and dadda multipliers in sub-threshold regime. Am. J. Eng. Applied Sci., 8: 702-716.

DOI: 10.3844/ajeassp.2015.702.716

Gusti, A.P. and Semin, 2016. The effect of vessel speed on fuel consumption and exhaust gas emissions. Am. J. Eng. Applied Sci., 9: 1046-1053. DOI: 10.3844/ajeassp.2016.1046.1053

Hassan, M., H. Mahjoub and M. Obed, 2012. Voicebased control of a DC servo motor. Am. J. Eng. Applied Sci., 5: 89-92.

DOI: 10.3844 /ajeassp.2012.89.92

Hasan, S. and M.H. El-Naas, 2016. Optimization of a combined approach for the treatment of carbide slurry and capture of $\mathrm{CO}_{2}$. Am. J. Eng. Applied Sci., 9: 449-457. DOI: 10.3844/ajeassp.2016.449.457

He, B., Z. Wang, Q. Li, H. Xie and R. Shen, 2013. An analytic method for the kinematics and dynamics of a multiple-backbone continuum robot. IJARS.

DOI: $10.5772 / 54051$
Helmy, A.K. and G.S. El-Taweel, 2010. Neural network change detection model for satellite images using textural and spectral characteristics. Am. J. Eng. Applied Sci., 3: 604-610. DOI: $10.3844 /$ ajeassp.2010.604.610

Hirun, W., 2016. Evaluation of interregional freight generation modelling methods by using nationwide commodity flow survey data. Am. J. Eng. Applied Sci., 9: 625-634.

DOI: 10.3844/ajeassp.2016.625.634

Ho, C.Y.F., B.W.K. Ling, S.G. Blasi, Z.W. Chi and W.C. Siu, 2011. Single step optimal block matched motion estimation with motion vectors having arbitrary pixel precisions. Am. J. Eng. Applied Sci., 4: 448-460. DOI: 10.3844/ajeassp.2011.448.460

Huang, B., S.H. Masood, M. Nikzad, P.R. Venugopal and A. Arivazhagan, 2016. Dynamic mechanical properties of fused deposition modelling processed polyphenylsulfone material. Am. J. Eng. Applied Sci., 9: 1-11. DOI: 10.3844/ajeassp.2016.1.11

Hypolite, B.P., W.T. Evariste and M.I. Adolphe, 2019. A 10GHZ low-offset dynamic comparator for highspeed and lower-power ADCS. Am. J. Eng. Applied Sci., 12: 156-165.

DOI: $10.3844 /$ ajeassp.2019.156.165

Idarwazeh, S., 2011. Inverse discrete Fourier transform-discrete Fourier transform techniques for generating and receiving spectrally efficient frequency division multiplexing signals. Am. J. Eng. Applied Sci., 4: 598-606.

DOI: 10.3844/ajeassp.2011.598.606

Iqbal, 2016. An overview of Energy Loss Reduction (ELR) software used in Pakistan by WAPDA for calculating transformer overloading, line losses and energy losses. Am. J. Eng. Applied Sci., 9: 442-448. DOI: 10.3844/ajeassp.2016.442.448

Ismail, M.I.S., Y. Okamoto, A. Okada and Y. Uno, 2011. Experimental investigation on micro-welding of thin stainless steel sheet by fiber laser. Am. J. Eng. Applied Sci., 4: 314-320.

DOI: 10.3844/ajeassp.2011.314.320

Jaber, A.A. and R. Bicker, 2016. Industrial robot fault detection based on statistical control chart. Am. J. Eng. Applied Sci., 9: 251-263.

DOI: 10.3844/ajeassp.2016.251.263

Jafari, N., A. Alsadoon, C.P. Withana, A. Beg and A. Elchouemi, 2016. Designing a comprehensive security framework for smartphones and mobile devices. Am. J. Eng. Applied Sci., 9: 724-734. DOI: 10.3844/ajeassp.2016.724.734

Jalil, M.I.A. and J. Sampe, 2013. Experimental investigation of thermoelectric generator modules with different technique of cooling system. Am. J. Eng. Applied Sci., 6: 1-7.

DOI: 10.3844/ajeassp.2013.1.7 
Jaoude, A.A. and K. El-Tawil, 2013. Analytic and nonlinear prognostic for vehicle suspension systems. Am. J. Eng. Applied Sci., 6: 42-56.

DOI: 10.3844 /ajeassp.2013.42.56

Jarahi, H., 2016. Probabilistic seismic hazard deaggregation for Karaj City (Iran). Am. J. Eng. Applied Sci., 9: 520-529.

DOI: 10.3844/ajeassp.2016.520.529

Jarahi, H. and S. Seifilaleh, 2016. Rock fall hazard zonation in Haraz Highway. Am. J. Eng. Applied Sci., 9: 371-379. DOI: 10.3844/ajeassp.2016.371.379

Jauhari, K., A. Widodo and I. Haryanto, 2016. Identification of a machine tool spindle critical frequency through modal and imbalance response analysis. Am. J. Eng. Applied Sci., 9: 213-221. DOI: 10.3844/ajeassp.2016.213.221

Jiang, J., Q. Chen and S. Nimbalkar, 2016. Field data based method for predicting long-term settlements. Am. J. Eng. Applied Sci., 9: 466-476.

DOI: 10.3844/ajeassp.2016.466.476

Kaewnai, S. and S. Wongwises, 2011. Improvement of the runner design of Francis turbine using computational fluid dynamics. Am. J. Eng. Applied Sci., 4: 540-547.

DOI: 10.3844/ajeassp.2011.540.547

Khalifa, A.H.N., A.H. Jabbar and J.A. Muhsin, 2015. Effect of exhaust gas temperature on the performance of automobile adsorption airconditioner. Am. J. Eng. Applied Sci., 8: 575-581. DOI: 10.3844/ajeassp.2015.575.581

Khalil, R., 2015. Credibility of 3D volume computation using GIS for pit excavation and roadway constructions. Am. J. Eng. Applied Sci., 8: 434-442. DOI: 10.3844/ajeassp.2015.434.442

Kamble, V.G. and N. Kumar, 2016. Fabrication and tensile property analysis of polymer matrix composites of graphite and silicon carbide as fillers. Am. J. Eng. Applied Sci., 9: 17-30.

DOI: 10.3844/ajeassp.2016.17.30

Kazakov, V.V., V.I. Yusupov, V.N. Bagratashvili, A.I. Pavlikov and V.A. Kamensky, 2016. Control of bubble formation at the optical fiber tip by analyzing ultrasound acoustic waves. Am. J. Eng. Applied Sci., 9: 921-927.

DOI: 10.3844/ajeassp.2016.921.927

Kechiche, O.B.H.B., H.B.A. Sethom, H. Sammoud and I.S. Belkhodja, 2011. Optimized high-frequency signal injection based permanent magnet synchronous motor rotor position estimation applied to washing machines. Am. J. Eng. Applied Sci., 4: 390-399. DOI: 10.3844/ajeassp.2011.390.399

Kuli, I., T.M. Abu-Lebdeh, E.H. Fini and S.A. Hamoush, 2016. The use of nano-silica for improving mechanical properties of hardened cement paste. Am. J. Eng. Applied Sci., 9: 146-154.

DOI: 10.3844/ajeassp.2016.146.154
Kumar, N.D., R.D. Ravali and PR. Srirekha, 2015. Design and realization of pre-amplifier and filters for on-board radar system. Am. J. Eng. Applied Sci., 8: 689-701. DOI: 10.3844/ajeassp.2015.689.701

Kunanoppadon, J., 2010. Thermal efficiency of a combined turbocharger set with gasoline engine. Am. J. Eng. Applied Sci., 3: 342-349.

DOI: 10.3844 ajeassp.2010.342.349

Kwon, S., Y. Tani, H. Okubo and T. Shimomura, 2010. Fixed-star tracking attitude control of spacecraft using single-gimbal control moment gyros. Am. J. Eng. Applied Sci., 3: 49-55.

DOI: 10.3844/ajeassp.2010.49.55

Lamarre, A., E.H. Fini and T.M. Abu-Lebdeh, 2016. Investigating effects of water conditioning on the adhesion properties of crack sealant. Am. J. Eng. Applied Sci., 9: 178-186.

DOI: 10.3844/ajeassp.2016.178.186

Lee, B.J., 2013. Geometrical derivation of differential kinematics to calibrate model parameters of flexible manipulator. Int. J. Adv. Robotic Sys. DOI: $10.5772 / 55592$

Li, R., B. Zhang, S. Xiu, H. Wang and L. Wang et al., 2015. Characterization of solid residues obtained from supercritical ethanol liquefaction of swine manure. Am. J. Eng. Applied Sci., 8: 465- 470. DOI: 10.3844/ajeassp.2015.465.470

Lin, W., B. Li, X. Yang and D. Zhang, 2013. Modelling and control of inverse dynamics for a 5-DOF parallel kinematic polishing machine. Int. J. Adv. Robotic Sys. DOI: 10.5772/54966

Liu, H., W. Zhou, X. Lai and S. Zhu, 2013. An efficient inverse kinematic algorithm for a PUMA560structured robot manipulator. IJARS.

DOI: $10.5772 / 56403$

Lubis, Z., A.N. Abdalla, Mortaza and R. Ghon, 2009. Mathematical modeling of the three phase induction motor couple to DC motor in hybrid electric vehicle. Am. J. Eng. Applied Sci., 2: 708-712. DOI: 10.3844/ajeassp.2009.708.712

Madani, D.A. and A. Dababneh, 2016. Rapid entire body assessment: A literature review. Am. J. Eng. Applied Sci., 9: 107-118.

DOI: 10.3844/ajeassp.2016.107.118

Malomar, G.E.B., A. Gueye, C. Mbow, V.B. Traore and A.C. Beye, 2016. Numerical study of natural convection in a square porous cavity thermally modulated on both side walls. Am. J. Eng. Applied Sci., 9: 591-598.

DOI: 10.3844/ajeassp.2016.591.598

Mansour, M.A.A., 2016. Developing an anthropometric database for Saudi students and comparing Saudi dimensions relative to Turkish and Iranian peoples. Am. J. Eng. Applied Sci., 9: 547-557. DOI: 10.3844/ajeassp.2016.547.557 
Maraveas, C., Z.C. Fasoulakis and K.D. Tsavdaridis, 2015. A review of human induced vibrations on footbridges. Am. J. Eng. Applied Sci., 8: 422-433. DOI: 10.3844/ajeassp.2015.422.433

Marghany, M. and M. Hashim, 2009. Robust of doppler centroid for mapping sea surface current by using radar satellite data. Am. J. Eng. Applied Sci., 2: 781-788.

DOI: 10.3844/ajeassp.2009.781.788

Martins, F.R., A.R. Gonçalves and E.B. Pereira, 2016. Observational study of wind shear in northeastern Brazil. Am. J. Eng. Applied Sci., 9: 484-504.

DOI: 10.3844/ajeassp.2016.484.504

Marzuki, M.A.L.B., M.H. Abd Halim and A.R.N. Mohamed, 2015. Determination of natural frequencies through modal and harmonic analysis of space frame race car chassis based on ANSYS. Am. J. Eng. Applied Sci., 8: 538-548.

DOI: 10.3844/ajeassp.2015.538.548

Mavukkandy, M.O., S. Chakraborty, T. Abbasi and S.A. Abbasi, 2016. A clean-green synthesis of platinum nanoparticles utilizing a pernicious weed lantana (Lantana Camara). Am. J. Eng. Applied Sci., 9: 84-90.

DOI: 10.3844/ajeassp.2016.84.90

Minghini, F., N. Tullini and F. Ascione, 2016. Updating Italian design guide CNR DT-205/2007 in view of recent research findings: Requirements for pultruded FRP profiles. Am. J. Eng. Applied Sci., 9: 702-712.

DOI: 10.3844/ajeassp.2016.702.712

Moezi, N., D. Dideban and A. Ketabi, 2008. A novel integrated SET based inverter for nano power electronic applications. Am. J. Eng. Applied Sci., 1: 219-222. DOI: 10.3844/ajeassp.2008.219.222

Mohamed, M.A., A.Y. Tuama, M. Makhtar, M.K. Awang and M. Mamat, 2016. The effect of RSA exponential key growth on the multi-core computational resource. Am. J. Eng. Applied Sci., 9: 1054-1061.

DOI: 10.3844/ajeassp.2016.1054.1061

Mohan, K.S.R., P. Jayabalan and A. Rajaraman, 2012. Properties of fly ash based coconut fiber composite. Am. J. Eng. Applied Sci., 5: 29-34.

DOI: 10.3844/ajeassp.2012.29.34

Mohseni, E. and K.D. Tsavdaridis, 2016. Effect of nanoalumina on pore structure and durability of class $f$ fly ash self-compacting mortar. Am. J. Eng. Applied Sci., 9: 323-333.

DOI: 10.3844/ajeassp.2016.323.333

Momani, M.A., T.A. Al Smadi, FM. Al Taweel and K.A. Ghaidan, 2011. GPS ionospheric total electron content and scintillation measurements during the October 2003 magnetic storm. Am. J. Eng. Applied Sci., 4: 301-306.

DOI: 10.3844/ajeassp.2011.301.306
Momta, P.S., J.O. Omoboh and M.I. Odigi, 2015. Sedimentology and depositional environment of D2 sand in part of greater ughelli depobelt, onshore Niger Delta, Nigeria. Am. J. Eng. Applied Sci., 8: 556-566.

DOI: 10.3844 /ajeassp.2015.556.566

Mondal, R., S. Sahoo and C.S. Rout, 2016. Mixed nickel cobalt manganese oxide nanorods for supercapacitor application. Am. J. Eng. Applied Sci., 9: 540-546. DOI: 10.3844/ajeassp.2016.540.546

Montgomery, J., T.M. Abu-Lebdeh, S.A. Hamoush and M. Picornell, 2016. Effect of nano-silica on the compressive strength of harden cement paste at different stages of hydration. Am. J. Eng. Applied Sci., 9: 166-177.

DOI: 10.3844/ajeassp.2016.166.177

Moretti, M.L., 2015. Seismic design of masonry and reinforced concrete infilled frames: A comprehensive overview. Am. J. Eng. Applied Sci., 8: 748-766. DOI: 10.3844/ajeassp.2015.748.766

Morse, A., M.M. Mansfield, R.M. Alley, H.A. Kerr and R.B. Bucinell, 2016. Traction enhancing products affect maximum torque at the shoe-floor interface: A potential increased risk of ACL injury. Am. J. Eng. Applied Sci., 9: 889-893.

DOI: 10.3844/ajeassp.2016.889.893

Moubarek, T. and A. Gharsallah, 2016. A six-port reflectometer calibration using Wilkinson power divider. Am. J. Eng. Applied Sci., 9: 274-280. DOI: 10.3844/ajeassp.2016.274.280

Nabilou, A., 2016a. Effect of parameters of selection and replacement drilling bits based on geomechanical factors: (Case study: Gas and oil reservoir in the Southwest of Iran). Am. J. Eng. Applied Sci., 9: 380-395.

DOI: 10.3844/ajeassp.2016.380.395

Nabilou, A., 2016b. Study of the parameters of Steam Assisted Gravity Drainage (SAGD) method for enhanced oil recovery in a heavy oil fractured carbonate reservoir. Am. J. Eng. Applied Sci., 9: 647-658. DOI: 10.3844/ajeassp.2016.647.658

Nachiengtai, T., W. Chim-Oye, S. Teachavorasinskun and W. Sa-Ngiamvibool, 2008. Identification of shear band using elastic shear wave propagation. Am. J. Eng. Applied Sci., 1: 188-191. DOI: 10.3844/ajeassp.2008.188.191

Nahas, R. and S.P. Kozaitis, 2014. Metric for the fusion of synthetic and real imagery from multimodal sensors. Am. J. Eng. Applied Sci., 7: 355-362. DOI: 10.3844/ajeassp.2014.355.362

Nandhakumar, S., V. Selladurai and S. Sekar, 2009. Numerical investigation of an industrial robot arm control problem using haar wavelet series. Am. J. Eng. Applied Sci., 2: 584-589.

DOI: 10.3844/ajeassp.2009.584.589 
Ng, K.C., M.Z. Yusoff, K. Munisamy, H. Hasini and N.H. Shuaib, 2008. Time-marching method for computations of high-speed compressible flow on structured and unstructured grid. Am. J. Eng. Applied Sci., 1: 89-94.

DOI: 10.3844 /ajeassp.2008.89.94

Obaiys, S.J., Z. Abbas, N.M.A. Nik Long, A.F. Ahmad and A. Ahmedov et al., 2016. On the general solution of first-kind hypersingular integral equations. Am. J. Eng. Applied Sci., 9: 195-201. DOI: 10.3844/ajeassp.2016.195.201

Odeh, S., R. Faqeh, L. Abu Eid and N. Shamasneh, 2009. Vision-based obstacle avoidance of mobile robot using quantized spatial model. Am. J. Eng. Applied Sci., 2: 611-619.

DOI: 10.3844/ajeassp.2009.611.619

Ong, A.T., A. Mustapha, Z.B. Ibrahim, S. Ramli and B.C. Eong, 2015. Real-time automatic inspection system for the classification of PCB flux defects. Am. J. Eng. Applied Sci., 8: 504-518.

DOI: 10.3844/ajeassp.2015.504.518

Opafunso, Z.O., I.I. Ozigis and I.A. Adetunde, 2009. Pneumatic and hydraulic systems in coal fluidized bed combustor. Am. J. Eng. Applied Sci., 2: 88-95. DOI: 10.3844/ajeassp.2009.88.95

Orlando, N. and E. Benvenuti, 2016. Advanced XFEM simulation of pull-out and debonding of steel bars and FRP-reinforcements in concrete beams. Am. J. Eng. Applied Sci., 9: 746-754.

DOI: 10.3844/ajeassp.2016.746.754

Pannirselvam, N., P.N. Raghunath and K. Suguna, 2008. Neural network for performance of glass fibre reinforced polymer plated RC beams. Am. J. Eng. Applied Sci., 1: 82-88.

DOI: 10.3844/ajeassp.2008.82.88

Pattanasethanon, S., 2010. The solar tracking system by using digital solar position sensor. Am. J. Eng. Applied Sci., 3: 678-682.

DOI: 10.3844/ajeassp.2010.678.682

Pérez-de León, G., V.E. Lamberti, R.D. Seals, T.M. Abu-Lebdeh and S.A. Hamoush, 2016. Gas atomization of molten metal: Part I. Numerical modeling conception. Am. J. Eng. Applied Sci., 9: 303-322. DOI: 10.3844/ajeassp.2016.303.322

Padula, F. and V. Perdereau, 2013. An on-line path planner for industrial manipulators. Int. J. Adv. Robotic Sys. DOI: 10.5772/55063

Perumaal, S. and N. Jawahar, 2013. Automated trajectory planner of industrial robot for pick-andplace task. IJARS. DOI: 10.5772/53940

Petrescu, F. and R. Petrescu, 1995a. Contributions to optimization of the polynomial motion laws of the stick from the internal combustion engine distribution mechanism. Bucharest, 1: 249-256.
Petrescu, F. and R. Petrescu, 1995b. Contributions to the synthesis of internal combustion engine distribution mechanisms. Bucharest, 1: 257-264.

Petrescu, F. and R. Petrescu, 1997a. Dynamics of cam mechanisms (exemplified on the classic distribution mechanism). Bucharest, 3: 353-358.

Petrescu, F. and R. Petrescu, 1997b. Contributions to the synthesis of the distribution mechanisms of internal combustion engines with a Cartesian coordinate method. Bucharest, 3: 359-364.

Petrescu, F. and R. Petrescu, 1997c. Contributions to maximizing polynomial laws for the active stroke of the distribution mechanism from internal combustion engines. Bucharest, 3: 365-370.

Petrescu, F. and R. Petrescu, 2000a. Synthesis of distribution mechanisms by the rectangular (Cartesian) coordinate method. Proceedings of the 8th National Conference on International Participation, (CIP' 00), Craiova, Romania, pp: 297-302.

Petrescu, F. and R. Petrescu, 2000b. The design (synthesis) of cams using the polar coordinate method (triangle method). Proceedings of the 8th National Conference on International Participation, (CIP' 00), Craiova, Romania, pp: 291-296.

Petrescu, F. and R. Petrescu, 2002a. Motion laws for cams. Proceedings of the International Computer Assisted Design, National Symposium with Participation, (SNP' 02), Braşov, pp: 321-326.

Petrescu, F. and R. Petrescu, 2002b. Camshaft dynamics elements. Proceedings of the International Computer Assisted Design, National Participation Symposium, (SNP' 02), Braşov, pp: 327-332.

Petrescu, F. and R. Petrescu, 2003. Some elements regarding the improvement of the engine design. Proceedings of the National Symposium, Descriptive Geometry, Technical Graphics and Design, (GTD' 03), Braşov, pp: 353-358.

Petrescu, F. and R. Petrescu, 2005a. The cam design for a better efficiency. Proceedings of the International Conference on Engineering Graphics and Design, (EGD’ 05), Bucharest, pp: 245-248.

Petrescu, F. and R. Petrescu, 2005b. Contributions at the dynamics of cams. Proceedings of the 9th IFToMM International Symposium on Theory of Machines and Mechanisms, (TMM' 05), Bucharest, Romania, pp: 123-128.

Petrescu, F. and R. Petrescu, 2005c. Determining the dynamic efficiency of cams. Proceedings of the 9th IFToMM International Symposium on Theory of Machines and Mechanisms, (TMM' 05), Bucharest, Romania, pp: 129-134.

Petrescu, F. and R. Petrescu, 2005d. An original internal combustion engine. Proceedings of the 9th IFToMM International Symposium on Theory of Machines and Mechanisms, (TMM' 05), Bucharest, Romania, pp: 135-140. 
Petrescu, F. and R. Petrescu, 2005e. Determining the mechanical efficiency of Otto engine's mechanism. Proceedings of the 9th IFToMM International Symposium on Theory of Machines and Mechanisms, (TMM 05), Bucharest, Romania, pp: 141-146.

Petrescu, F.I. and R.V. Petrescu, 2011a. Mechanical Systems, Serial and Parallel (Romanian). 1st Edn., LULU Publisher, London, UK, pp: 124.

Petrescu, F.I.T. and RV. Petrescu, 2011b. Trenuri Planetare. 1st Edn., Createspace Independent Pub., ISBN-13: 978-1468030419, pp: 104.

Petrescu, F.I. and R.V. Petrescu, 2012a. Kinematics of the planar quadrilateral mechanism. ENGEVISTA, 14: 345-348.

Petrescu, F.I. and R.V. Petrescu, 2012b. MecatronicaSisteme Seriale si Paralele. 1st Edn., Create Space Publisher, USA, pp: 128.

Petrescu, F.I. and R.V. Petrescu, 2013a. Cinematics of the 3R dyad. ENGEVISTA, 15: 118-124.

Petrescu, F.I.T. and R.V. Petrescu, 2013b. Forces and efficiency of cams. Int. Rev. Mech. Eng., 7: 507-511.

Petrescu, F.I.T. and R.V. Petrescu, 2013c. Cams with high efficiency. Int. Rev. Mech. Eng., 7: 599-606.

Petrescu, F.I.T. and R.V. Petrescu, 2013d. An algorithm for setting the dynamic parameters of the classic distribution mechanism. Int. Rev. Modell. Simulat., 6: 1637-1641.

Petrescu, F.I.T. and R.V. Petrescu, 2013e. Dynamic synthesis of the rotary cam and translated tappet with roll. Int. Rev. Modell. Simulat., 6: 600-607.

Petrescu, F.I.T. and R.V. Petrescu, 2014a. Parallel moving mechanical systems. Independent J. Manage. Product., 5: 564-580.

Petrescu, F.I.T. and R.V. Petrescu, 2014b. Cam gears dynamics in the classic distribution. Independent $\mathrm{J}$. Manage. Product., 5: 166-185.

Petrescu, F.I.T. and R.V. Petrescu, 2014c. Highefficiency gears synthesis by avoid the interferences. Independent J. Manage. Product., 5: 275-298.

Petrescu, F.I.T. and R.V. Petrescu, 2014d. Gear design. J. ENGEVISTA, 16: 313-328.

Petrescu, F.I.T. and R.V. Petrescu, 2014e. Kinetostatic of the $3 \mathrm{R}$ dyad (or 2R module). J. ENGEVISTA, 16: 314-321.

Petrescu, F.I.T. and R.V. Petrescu, 2014f. Balancing Otto engines. Int. Rev. Mech. Eng., 8: 473-480.

Petrescu, F.I.T. and R.V. Petrescu, 2014g. Machine equations to the classical distribution. Int. Rev. Mech. Eng., 8: 309-316.

Petrescu, F.I.T. and R.V. Petrescu, 2014h. Forces of internal combustion heat engines. Int. Rev. Modell. Simulat., 7: 206-212.

Petrescu, F.I.T. and R.V. Petrescu, 2014i. Determination of the yield of internal combustion thermal engines. Int. Rev. Mech. Eng., 8: 62-67.
Petrescu, F.I.T. and R.V. Petrescu, 2015a. Forces at the main mechanism of a railbound forging manipulator. Independent J. Manage. Product., 6: 904-921.

Petrescu, F.I.T. and R.V. Petrescu, 2015b. Kinematics at the main mechanism of a railbound forging manipulator. Independent J. Manage. Product., 6: 711-729.

Petrescu, F.I.T. and R.V. Petrescu, 2015c. Machine motion equations. Independent J. Manage. Product., 6: 773-802.

Petrescu F.I.T. and R.V. Petrescu, 2015d. Presenting a railbound forging manipulator. Applied Mech. Mater., 762: 219-224.

Petrescu, F.I.T. and R.V. Petrescu, 2015e. About the anthropomorphic robots. J. ENGEVISTA, 17: 1-15.

Petrescu, F.I. and R.V. Petrescu, 2016a. Parallel moving mechanical systems kinematics. ENGEVISTA, 18 455-491.

Petrescu, F.I. and R.V. Petrescu, 2016b. Direct and inverse kinematics to the anthropomorphic robots. ENGEVISTA, 18: 109-124.

Petrescu, F.I. and R.V. Petrescu, 2016c. Dynamic cinematic to a structure 2R. Revista Geintec-Gestao Inovacao E Tecnol., 6: 3143-3154.

Petrescu, FIT. and R.V. Petrescu, 2016d. An Otto engine dynamic model. Independent J. Manage. Product., 7: 038-048.

Petrescu, N. and F.I.T. Petrescu, 2018a. Elementary structure of matter can be studied with new quantum computers. SSRN.

Petrescu, N. and F.I.T. Petrescu, 2018b. Geometriccinematic synthesis of planetary mechanisms. SSRN.

Petrescu, F.I.T., 2011. Teoria Mecanismelor si a Masinilor: Curs Si Aplicatii. 1st Edn., CreateSpace Independent Publishing Platform. ISBN-10: 1468015826. pp: 432.

Petrescu, F.I.T., 2015a. Geometrical synthesis of the distribution mechanisms. Am. J. Eng. Applied Sci., 8: 63-81. DOI: 10.3844/ajeassp.2015.63.81

Petrescu, F.I.T., 2015b. Machine motion equations at the internal combustion heat engines. Am. J. Eng. Applied Sci., 8: 127-137. DOI: 10.3844/ajeassp.2015.127.137

Petrescu, F.I.T., 2015c. Machine motion equations at the internal combustion heat engines. SSRN.

Petrescu, F.I.T., 2018a. Dynamic models of rigid memory mechanisms. SSRN.

Petrescu, F.I.T., 2018b. About the triton structure. SSRN.

Petrescu, F.I., B. Grecu, A. Comanescu and R.V. Petrescu, 2009. Some mechanical design elements. Proceeding of the International Conference on Computational Mechanics and Virtual Engineering, (MVE’ 09), Braşov, pp: 520-525. 
Petrescu, R.V., R. Aversa, A. Apicella and F.I. Petrescu, 2016a. Future medicine services robotics. Am. J. Eng. Applied Sci., 9: 1062-1087. DOI: 10.3844/ajeassp.2016.1062.1087

Petrescu, F.I.T., A. Apicella, A. Raffaella, R.V. Petrescu and J.K. Calautit et al., 2016b. Something about the mechanical moment of Inertia. Am. J. Applied Sci., 13: 1085-1090. DOI: 10.3844/ajassp.2016.1085.1090

Petrescu, R.V., R. Aversa, B. Akash, R. Bucinell and J. Corchado et al., 2017a. Yield at thermal engines internal combustion. Am. J. Eng. Applied Sci., 10: 243-251. DOI: 10.3844/ajeassp.2017.243.251

Petrescu, R.V., R. Aversa, B. Akash, B. Ronald and J. Corchado et al., 2017b. Velocities and accelerations at the 3R mechatronic systems. Am. J. Eng. Applied Sci., 10: 252-263. DOI: 10.3844/ajeassp.2017.252.263

Petrescu, R.V., R. Aversa, B. Akash, R. Bucinell and J. Corchado et al., 2017c. Anthropomorphic solid structures n-r kinematics. Am. J. Eng. Applied Sci., 10: 279-291. DOI: 10.3844/ajeassp.2017.279.291

Petrescu, R.V., R. Aversa, B. Akash, R. Bucinell and J. Corchado et al., 2017d. Inverse kinematics at the anthropomorphic robots, by a trigonometric method. Am. J. Eng. Applied Sci., 10: 394-411.

DOI: 10.3844/ajeassp.2017.394.411

Petrescu, R.V., R. Aversa, B. Akash, R. Bucinell and J. Corchado et al., 2017e. Forces at internal combustion engines. Am. J. Eng. Applied Sci., 10: 382-393. DOI: 10.3844/ajeassp.2017.382.393

Petrescu, R.V., R. Aversa, B. Akash, R. Bucinell and J. Corchado et al., 2017f. Gears-Part I. Am. J. Eng. Applied Sci., 10: 457-472. DOI: 10.3844/ajeassp.2017.457.472

Petrescu, R.V., R. Aversa, B. Akash, R. Bucinell and J. Corchado et al., 2017g. Gears-part II. Am. J. Eng. Applied Sci., 10: 473-483.

DOI: 10.3844/ajeassp.2017.473.483

Petrescu, R.V., R. Aversa, B. Akash, R. Bucinell and J. Corchado et al., 2017h. Cam-gears forces, velocities, powers and efficiency. Am. J. Eng. Applied Sci., 10: 491-505. DOI: 10.3844/ajeassp.2017.491.505

Petrescu, R.V., R. Aversa, B. Akash, R. Bucinell and J. Corchado et al., 2017i. Dynamics of mechanisms with cams illustrated in the classical distribution. Am. J. Eng. Applied Sci., 10: 551-567.

DOI: 10.3844/ajeassp.2017.551.567

Petrescu, R.V., R. Aversa, B. Akash, R. Bucinell and J. Corchado et al., 2017j. Testing by non-destructive control. Am. J. Eng. Applied Sci., 10: 568-583. DOI: 10.3844/ajeassp.2017.568.583

Petrescu, R.V., R. Aversa, A. Apicella and F.I.T. Petrescu, 2017k. Transportation engineering. Am. J. Eng. Applied Sci., 10: 685-702.

DOI: 10.3844/ajeassp.2017.685.702
Petrescu, R.V., R. Aversa, S. Kozaitis, A. Apicella and F.I.T. Petrescu, 20171. The quality of transport and environmental protection, part I. Am. J. Eng. Applied Sci., 10: 738-755.

DOI: $10.3844 /$ ajeassp.2017.738.755

Petrescu, R.V., R. Aversa, B. Akash, R. Bucinell and J. Corchado et al., $2017 \mathrm{~m}$. Modern propulsions for aerospace-a review. J. Aircraft Spacecraft Technol., 1: 1-8. DOI: 10.3844/jastsp.2017.1.8

Petrescu, R.V., R. Aversa, B. Akash, R. Bucinell and J. Corchado et al., 2017n. Modern propulsions for aerospace-part II. J. Aircraft Spacecraft Technol., 1: 9-17. DOI: 10.3844/jastsp.2017.9.17

Petrescu, R.V., R. Aversa, B. Akash, R. Bucinell and J. Corchado et al., 2017o. History of aviation-a short review. J. Aircraft Spacecraft Technol., 1: 30-49. DOI: 10.3844 jastsp.2017.30.49

Petrescu, R.V., R. Aversa, B. Akash, R. Bucinell and J. Corchado et al., 2017p. Lockheed martin-a short review. J. Aircraft Spacecraft Technol., 1: 50-68. DOI: 10.3844 /jastsp.2017.50.68

Petrescu, R.V., R. Aversa, B. Akash, J. Corchado and F. Berto et al., 2017q. Our universe. J. Aircraft Spacecraft Technol., 1: 69-79. DOI: 10.3844/jastsp.2017.69.79

Petrescu, R.V., R. Aversa, B. Akash, J. Corchado and et al., 2017r. What is a UFO? J. Aircraft Spacecraft Technol., 1: 80-90. DOI: 10.3844/jastsp.2017.80.90

Petrescu, R.V., R. Aversa, B. Akash, J. Corchado and F. Berto et al., 2017s. About bell helicopter FCX-001 concept aircraft-a short review. J. Aircraft Spacecraft Technol., 1: 91-96. DOI: 10.3844/jastsp.2017.91.96

Petrescu, R.V., R. Aversa, B. Akash, J. Corchado and F. Berto et al., 2017t. Home at airbus. J. Aircraft Spacecraft Technol., 1: 97-118. DOI: $10.3844 /$ jastsp.2017.97.118

Petrescu, R.V., R. Aversa, B. Akash, J. Corchado and F. Berto et al., 2017u. Airlander. J. Aircraft Spacecraft Technol., 1: 119-148. DOI: $10.3844 /$ jastsp.2017.119.148

Petrescu, R.V., R. Aversa, B. Akash, J. Corchado and F. Berto et al., 2017v. When boeing is dreaming-a review. J. Aircraft Spacecraft Technol., 1: 149-161. DOI: 10.3844/jastsp.2017.149.161

Petrescu, R.V., R. Aversa, B. Akash, J. Corchado and F. Berto et al., 2017w. About Northrop Grumman. J. Aircraft Spacecraft Technol., 1: 162-185. DOI: $10.3844 /$ jastsp.2017.162.185

Petrescu, R.V., R. Aversa, B. Akash, J. Corchado and F. Berto et al., 2017x. Some special aircraft. J. Aircraft Spacecraft Technol., 1: 186-203. DOI: $10.3844 /$ jastsp.2017.186.203

Petrescu, R.V., R. Aversa, B. Akash, J. Corchado and F. Berto et al., 2017y. About helicopters. J. Aircraft Spacecraft Technol., 1: 204-223. DOI: $10.3844 /$ jastsp.2017.204.223 
Petrescu, R.V., R. Aversa, B. Akash, F. Berto and A. Apicella et al., 2017z. The modern flight. J. Aircraft Spacecraft Technol., 1: 224-233. DOI: 10.3844/jastsp.2017.224.233

Petrescu, R.V., R. Aversa, B. Akash, F. Berto and A. Apicella et al., 2017aa. Sustainable energy for aerospace vessels. J. Aircraft Spacecraft Technol., 1: 234-240. DOI: 10.3844/jastsp.2017.234.240

Petrescu, R.V., R. Aversa, B. Akash, F. Berto and A. Apicella et al., 2017ab. Unmanned helicopters. J. Aircraft Spacecraft Technol., 1: 241-248. DOI: 10.3844 /jastsp.2017.241.248

Petrescu, R.V., R. Aversa, B. Akash, F. Berto and A. Apicella et al., 2017ac. Project HARP. J. Aircraft Spacecraft Technol., 1: 249-257. DOI: $10.3844 /$ jastsp.2017.249.257

Petrescu, R.V., R. Aversa, B. Akash, F. Berto and A. Apicella et al., 2017ad. Presentation of Romanian engineers who contributed to the development of global aeronautics-part I. J. Aircraft Spacecraft Technol., 1: 258-271. DOI: 10.3844/jastsp.2017.258.271

Petrescu, R.V., R. Aversa, B. Akash, F. Berto and A. Apicella et al., 2017ae. A first-class ticket to the planet mars, please. J. Aircraft Spacecraft Technol., 1: 272-281. DOI: 10.3844/jastsp.2017.272.281

Petrescu, R.V.V., R. Aversa, S. Kozaitis, A. Apicella and F.I. Petrescu, 2017af. Some basic reactions in nuclear fusion. SSRN.

Petrescu, R.V.V., R. Aversa, S. Kozaitis, A. Apicella and F.I. Petrescu, 2017ag. Deuteron Dimensions. SSRN.

Petrescu, R.V.V., R. Aversa, S. Kozaitis, A. Apicella and F.I. Petrescu, 2017ah. Some proposed solutions to achieve nuclear fusion. SSRN.

Petrescu, R.V.V., R. Aversa, S. Kozaitis, A. Apicella and F.I. Petrescu, 2017ai. Dynamic elements at MP3R. SSRN.

Petrescu, R.V.V., R. Aversa, S. Kozaitis, A. Apicella and F.I. Petrescu, 2017aj. Nikola tesla. SSRN.

Petrescu, R.V., R. Aversa, A. Apicella, M.M. Mirsayar and S. Kozaitis et al., 2018a. NASA started a propeller set on board voyager 1 after 37 years of break. Am. J. Eng. Applied Sci., 11: 66-77. DOI: 10.3844/ajeassp.2018.66.77

Petrescu, R.V., R. Aversa, A. Apicella, M.M. Mirsayar and S. Kozaitis et al., 2018b. There is life on mars? Am. J. Eng. Applied Sci., 11: 78-91.

DOI: 10.3844/ajeassp.2018.78.91

Petrescu, R.V., R. Aversa, A. Apicella and F.I.T. Petrescu, 2018c. Friendly environmental transport. Am. J. Eng. Applied Sci., 11: 154-165. DOI: 10.3844/ajeassp.2018.154.165

Petrescu, R.V., R. Aversa, B. Akash, T.M. Abu-Lebdeh and A. Apicella et al., 2018d. Buses running on gas. Am. J. Eng. Applied Sci., 11: 186-201.

DOI: 10.3844/ajeassp.2018.186.201
Petrescu, R.V., R. Aversa, B. Akash, T.M. Abu-Lebdeh and A. Apicella et al., 2018e. Some aspects of the structure of planar mechanisms. Am. J. Eng. Applied Sci., 11: 245-259. DOI: 10.3844/ajeassp.2018.245.259

Petrescu, RV., R. Aversa, T.M. Abu-Lebdeh, A. Apicella and F.I.T. Petrescu, 2018f. The forces of a simple carrier manipulator. Am. J. Eng. Applied Sci., 11: 260-272. DOI: 10.3844/ajeassp.2018.260.272

Petrescu, RV., R. Aversa, T.M. Abu-Lebdeh, A. Apicella and F.I.T. Petrescu, 2018g. The dynamics of the otto engine. Am. J. Eng. Applied Sci., 11: 273-287. DOI: 10.3844/ajeassp.2018.273.287

Petrescu, RV., R. Aversa, T.M. Abu-Lebdeh, A. Apicella and F.I.T. Petrescu, 2018h. NASA satellites help us to quickly detect forest fires. Am. J. Eng. Applied Sci., 11: 288-296.

DOI: 10.3844 ajeassp.2018.288.296

Petrescu, RV., R. Aversa, T.M. Abu-Lebdeh, A. Apicella and F.I.T. Petrescu, 2018i. Kinematics of a mechanism with a triad. Am. J. Eng. Applied Sci., 11: 297-308. DOI: 10.3844/ajeassp.2018.297.308

Petrescu, R.V., R. Aversa, A. Apicella and F.I.T. Petrescu, 2018j. Romanian engineering "on the wings of the wind". J. Aircraft Spacecraft Technol., 2: 1-18. DOI: 10.3844/jastsp.2018.1.18

Petrescu, R.V., R. Aversa, A. Apicella and F.I.T. Petrescu, 2018k. NASA Data used to discover eighth planet circling distant star. J. Aircraft Spacecraft Technol., 2: 19-30.

DOI: $10.3844 /$ jastsp.2018.19.30

Petrescu, R.V., R. Aversa, A. Apicella and F.I.T. Petrescu, 20181. NASA has found the most distant black hole. J. Aircraft Spacecraft Technol., 2: 31-39. DOI: 10.3844/jastsp.2018.31.39

Petrescu, R.V., R. Aversa, A. Apicella and F.I.T. Petrescu, 2018m. Nasa selects concepts for a new mission to titan, the moon of saturn. J. Aircraft Spacecraft Technol., 2: 40-52.

DOI: $10.3844 /$ jastsp.2018.40.52

Petrescu, R.V., R. Aversa, A. Apicella and F.I.T. Petrescu, 2018n. NASA sees first in 2018 the direct proof of ozone hole recovery. J. Aircraft Spacecraft Technol., 2: 53-64. DOI: 10.3844/jastsp.2018.53.64

Petrescu, R.V., R. Aversa, A. Apicella and F.I.T. Petrescu, 2018o. Dynamic synthesis of a dual-clutch automatic gearboxes. SSRN.

Petrescu, R.V., R. Aversa, A. Apicella and F.I.T. Petrescu, 2018p. Dynamic synthesis of a classic, manual gearbox. SSRN.

Petrescu, R.V., R. Aversa, A. Apicella and F.I.T. Petrescu, 2018q. The dynamics of the Otto engine. SSRN.

Petrescu, R.V., R. Aversa, A. Apicella and F.I.T. Petrescu, 2018r. Kinematics of a mechanism with a triad. SSRN. 
Petrescu, F.I.T., T.M. Abu-Lebdeh and A. Apicella, 2018s. Presentation of a mechanism with a Maltese cross (Geneva Driver). SSRN.

Petrescu, F.I.T., T.M. Abu-Lebdeh and A. Apicella, 2018t. An analytical method for determining forces within a triad. SSRN.

Petrescu, F.I.T., T.M. Abu-Lebdeh and A. Apicella, 2018u. Study of an oscillating sliding mechanism. SSRN.

Petrescu, F.I.T., T.M. Abu-Lebdeh and A. Apicella, 2018v. Presentation of the mechanism in the cross. SSRN.

Pisello, A.L., G. Pignatta, C. Piselli, V.L. Castaldo and F. Cotana, 2016. Investigating the dynamic thermal behavior of building envelope in summer conditions by means of in-field continuous monitoring. Am. J. Eng. Applied Sci., 9: 505-519.

DOI: 10.3844/ajeassp.2016.505.519

Pourmahmoud, N., 2008. Rarefied gas flow modeling inside rotating circular cylinder. Am. J. Eng. Applied Sci., 1: 62-65.

DOI: 10.3844/ajeassp.2008.62.65

Pravettoni, M., C.S.P. Lòpez and R.P. Kenny, 2016. Impact of the edges of a backside diffusive reflector on the external quantum efficiency of luminescent solar concentrators: Experimental and computational approach. Am. J. Eng. Applied Sci., 9: 53-63.

DOI: 10.3844 /ajeassp.2016.53.63

Qutbodin, K., 2010. Merging autopilot/flight control and navigation-flight management systems. Am. J. Eng. Applied Sci., 3: 629-630.

DOI: 10.3844/ajeassp.2010.629.630

Rajbhandari, S., Z. Ghassemlooy and M. Angelova, 2011. The performance of a dual header pulse interval modulation in the presence of artificial light interferences in an indoor optical wireless communications channel with wavelet denoising. Am. J. Eng. Applied Sci., 4: 513-519.

DOI: 10.3844/ajeassp.2011.513.519

Rajput, R.S., S. Pandey and S. Bhadauria, 2016. Correlation of biodiversity of algal genera with special reference to the waste water effluents from industries. Am. J. Eng. Applied Sci., 9: 1127-1133. DOI: 10.3844/ajeassp.2016.1127.1133

Rajupillai, K., S. Palaniammal and K. Bommuraju, 2015. Computational intelligence and application of frame theory in communication systems. Am. J. Eng. Applied Sci., 8: 633-637.

DOI: 10.3844/ajeassp.2015.633.637

Raptis, K.G., G.A. Papadopoulos, T.N. Costopoulos and A.D. Tsolakis, 2011. Experimental study of load sharing in roller-bearing contact by caustics and photoelasticity. Am. J. Eng. Applied Sci., 4: 294-300. DOI: 10.3844/ajeassp.2011.294.300

Rama, G., D. Marinkovic and M. Zehn, 2016. Efficient co-rotational 3-node shell element. Am. J. Eng. Applied Sci., 9: 420-431.

DOI: 10.3844/ajeassp.2016.420.431
Rea, P. and E. Ottaviano, 2016. Analysis and mechanical design solutions for sit-to-stand assisting devices. Am. J. Eng. Applied Sci., 9: 1134-1143. DOI: 10.3844/ajeassp.2016.1134.1143

Rhode-Barbarigos, L., V. Charpentier, S. Adriaenssens and O. Baverel, 2015. Dialectic form finding of structurally integrated adaptive structures. Am. J. Eng. Applied Sci., 8: 443-454.

DOI: 10.3844/ajeassp.2015.443.454

Riccio, A., U. Caruso, A. Raimondo and A. Sellitto, 2016a. Robustness of XFEM method for the simulation of cracks propagation in fracture mechanics problems. Am. J. Eng. Applied Sci., 9: 599-610. DOI: 10.3844/ajeassp.2016.599.610

Riccio, A., R. Cristiano and S. Saputo, 2016b. A brief introduction to the bird strike numerical simulation. Am. J. Eng. Applied Sci., 9: 946-950. DOI: 10.3844/ajeassp.2016.946.950

Rich, F. and M.A. Badar, 2016. Statistical analysis of auto dilution Vs manual dilution process in inductively coupled plasma spectrometer tests. Am. J. Eng. Applied Sci., 9: 611-624.

DOI: 10.3844/ajeassp.2016.611.624

Rohit, K. and S. Dixit, 2016. Mechanical properties of waste Biaxially Oriented Polypropylene metallized films (BOPP), LLDPE: LDPE films with sisal fibres. Am. J. Eng. Applied Sci., 9: 913-920. DOI: 10.3844/ajeassp.2016.913.920

Rulkov, N.F., A.M. Hunt, P.N. Rulkov and A.G. Maksimov, 2016. Quantization of map-based neuronal model for embedded simulations of neurobiological networks in real-time. Am. J. Eng. Applied Sci., 9: 973-984. DOI: 10.3844/ajeassp.2016.973.984

Saikia, A. and N. Karak, 2016. Castor oil based epoxy/clay nanocomposite for advanced applications. Am. J. Eng. Applied Sci., 9: 31-40. DOI: 10.3844/ajeassp.2016.31.40

Sallami, A., N. Zanzouri and M. Ksouri, 2016. Robust diagnosis of a DC motor by bond graph approach. Am. J. Eng. Applied Sci., 9: 432-438. DOI: 10.3844/ajeassp.2016.432.438

Samantaray, K.S., S. Sahoo and C.S. Rout, 2016. Hydrothermal synthesis of CuWO4-reduced graphene oxide hybrids and supercapacitor application. Am. J. Eng. Applied Sci., 9: 584-590. DOI: 10.3844/ajeassp.2016.584.590

Santos, F.A. and C. Bedon, 2016. Preliminary experimental and finite-element numerical assessment of the structural performance of SMAreinforced GFRP systems. Am. J. Eng. Applied Sci., 9: 692-701. DOI: 10.3844/ajeassp.2016.692.701

Semin, A.R. Ismail and R.A. Bakar, 2009a. Combustion temperature effect of diesel engine convert to compressed natural gas engine. Am. J. Eng. Applied Sci., 2: 212-216.

DOI: 10.3844/ajeassp.2009.212.216 
Semin, A.R. Ismail and R.A. Bakar, 2009b. Effect of diesel engine converted to sequential port injection compressed natural gas engine on the cylinder pressure Vs crank angle in variation engine speeds. Am. J. Eng. Applied Sci., 2: 154-159. DOI: 10.3844/ajeassp.2009.154.159

Semin S., A.R. Ismail and R.A. Bakar, 2009c. Diesel engine convert to port injection $\mathrm{CNG}$ engine using gaseous injector nozzle multi holes geometries improvement: A review. Am. J. Eng. Applied Sci., 2: 268-278. DOI: 10.3844/ajeassp.2009.268.278

Semin and R.A. Bakar, 2008. A technical review of compressed natural gas as an alternative fuel for internal combustion engines. Am. J. Eng. Applied Sci., 1: 302-311. DOI: 10.3844/ajeassp.2008.302.311

Sepúlveda, J.A.M., 2016. Outlook of municipal solid waste in Bogota (Colombia). Am. J. Eng. Applied Sci., 9: 477-483. DOI: 10.3844/ajeassp.2016.477.483

Serebrennikov, A., D. Serebrennikov and Z. Hakimov, 2016. Polyethylene pipeline bending stresses at an installation. Am. J. Eng. Applied Sci., 9: 350-355. DOI: 10.3844/ajeassp.2016.350.355

Shanmugam, K., 2016. Flow dynamic behavior of fish oil/silver nitrate solution in mini-channel, effect of alkane addition on flow pattern and interfacial tension. Am. J. Eng. Applied Sci., 9: 236-250.

DOI: 10.3844/ajeassp.2016.236.250

Shruti, 2016. Comparison in cover media under stegnography: Digital media by hide and seek approach. Am. J. Eng. Applied Sci., 9: 297-302. DOI: 10.3844/ajeassp.2016.297.302

Stavridou, N., E. Efthymiou and C.C. Baniotopoulos, 2015a. Welded connections of wind turbine towers under fatigue loading: Finite element analysis and comparative study. Am. J. Eng. Applied Sci., 8: 489-503. DOI: 10.3844/ajeassp.2015.489.503

Stavridou, N., E. Efthymiou and C.C. Baniotopoulos, 2015b. Verification of anchoring in foundations of wind turbine towers. Am. J. Eng. Applied Sci., 8: 717-729. DOI: 10.3844/ajeassp.2015.717.729

Suarez, L., T.M. Abu-Lebdeh, M. Picornell and S.A. Hamoush, 2016. Investigating the role of fly ash and silica fume in the cement hydration process. Am. J. Eng. Applied Sci., 9: 134-145.

DOI: 10.3844/ajeassp.2016.134.145

Syahrullah, O.I. and N. Sinaga, 2016. Optimization and prediction of motorcycle injection system performance with feed-forward back-propagation method Artificial Neural Network (ANN). Am. J. Eng. Applied Sci., 9: 222-235.

DOI: 10.3844/ajeassp.2016.222.235

Sylvester, O., I. Bibobra and O.N. Ogbon, 2015a. Well test and PTA for reservoir characterization of key properties. Am. J. Eng. Applied Sci., 8: 638-647. DOI: 10.3844/ajeassp.2015.638.647
Sylvester, O., I. Bibobra and O. Augustina, 2015b. Report on the evaluation of Ugua $\mathrm{J} 2$ and $\mathrm{J} 3$ reservoir performance. Am. J. Eng. Applied Sci., 8: 678-688. DOI: 10.3844/ajeassp.2015.678.688

Taher, S.A., R. Hematti and M. Nemati, 2008. Comparison of different control strategies in GAbased optimized UPFC controller in electric power systems. Am. J. Eng. Applied Sci., 1: 45-52.

DOI: 10.3844/ajeassp.2008.45.52

Takeuchi, T., Y. Kinouchi, R. Matsui and T. Ogawa, 2015. Optimal arrangement of energy-dissipating members for seismic retrofitting of truss structures. Am. J. Eng. Applied Sci., 8: 455-464.

DOI: 10.3844 ajeassp.2015.455.464

Theansuwan, W. and K. Triratanasirichai, 2011. The biodiesel production from roast Thai sausage oil by transesterification reaction. Am. J. Eng. Applied Sci., 4: 130-132.

DOI: 10.3844/ajeassp.2011.130.132

Thongwan, T., A. Kangrang and S. Homwuttiwong, 2011. An estimation of rainfall using fuzzy setgenetic algorithms model. Am. J. Eng. Applied Sci., 4: 77-81. DOI: 10.3844/ajeassp.2011.77.81

Tourab, W., A. Babouri and M. Nemamcha, 2011. Experimental study of electromagnetic environment in the vicinity of high voltage lines. Am. J. Eng. Applied Sci., 4: 209-213.

DOI: 10.3844/ajeassp.2011.209.213

Tsolakis, A.D. and K.G. Raptis, 2011. Comparison of maximum gear-tooth operating bending stresses derived from niemann's analytical procedure and the finite element method. Am. J. Eng. Applied Sci., 4: 350-354. DOI: 10.3844/ajeassp.2011.350.354

Vernardos, S.M. and C.J. Gantes, 2015. Cross-section optimization of sandwich-type cylindrical wind turbine towers. Am. J. Eng. Applied Sci., 8: 471-480. DOI: 10.3844/ajeassp.2015.471.480

Wang, L., T. Liu, Y. Zhang and X. Yuan, 2016. A methodology for continuous evaluation of cloud resiliency. Am. J. Eng. Applied Sci., 9: 264-273. DOI: 10.3844/ajeassp.2016.264.273

Wang, L., G. Wang and C.A. Alexander, 2015. Confluences among big data, finite element analysis and high-performance computing. Am. J. Eng. Applied Sci., 8: 767-774.

DOI: 10.3844/ajeassp.2015.767.774

Wang, J. and Y. Yagi, 2016. Fragment-based visual tracking with multiple representations. Am. J. Eng. Applied Sci., 9: 187-194.

DOI: 10.3844/ajeassp.2016.187.194

Waters, C., S. Ajinola and M. Salih, 2016. Dissolution sintering technique to create porous copper with sodium chloride using polyvinyl alcohol solution through powder metallurgy. Am. J. Eng. Applied Sci. 9: 155-165. DOI: 10.3844/ajeassp.2016.155.165 
Wessels, L. and H. Raad, 2016. Recent advances in point of care diagnostic tools: A review. Am. J. Eng. Applied Sci., 9: 1088-1095.

DOI: 10.3844/ajeassp.2016.1088.1095

Yang, M.F. and Y. Lin, 2015. Process is unreliable and quantity discounts supply chain integration inventory model. Am. J. Eng. Applied Sci., 8: 602-610. DOI: 10.3844/ajeassp.2015.602.610

Yeargin, R., R. Ramey and C. Waters, 2016. Porosity analysis in porous brass using dual approaches. Am. J. Eng. Applied Sci., 9: 91-97.

DOI: 10.3844/ajeassp.2016.91.97

You, M., X. Huang, M. Lin, Q. Tong and X. Li et al., 2016. Preparation of $\mathrm{LiCoMnO}_{4}$ assisted by hydrothermal approach and its electrochemical performance. Am. J. Eng. Applied Sci., 9: 396-405. DOI: 10.3844/ajeassp.2016.396.405

Zeferino, R.S., J.A.R. Ramón, E. de Anda Reyes, R.S. González and U. Pal, 2016. Large scale synthesis of $\mathrm{ZnO}$ nanostructures of different morphologies through solvent-free mechanochemical synthesis and their application in photocatalytic dye degradation. Am. J. Eng. Applied Sci., 9: 41-52. DOI: 10.3844/ajeassp.2016.41.52

Zhao, B., 2013. Identification of multi-cracks in the gate rotor shaft based on the wavelet finite element method. Am. J. Eng. Applied Sci., 6: 309-319.

DOI: 10.3844/ajeassp.2013.309.319

Zheng, H. and S. Li, 2016. Fast and robust maximum power point tracking for solar photovoltaic systems. Am. J. Eng. Applied Sci., 9: 755-769.

DOI: 10.3844/ajeassp.2016.755.769

Zotos, I.S. and T.N. Costopoulos, 2009. On the use of rolling element bearings' models in Precision maintenance. Am. J. Eng. Applied Sci., 2: 344-352. DOI: 10.3844/ajeassp.2009.344.352
Zulkifli, R., K. Sopian, S. Abdullah and M.S. Takriff, 2008. Effect of pulsating circular hot air jet frequencies on local and average nusselt number. Am. J. Eng. Applied Sci., 1: 57-61. DOI: 10.3844/ajeassp.2008.57.61

Zulkifli, R., K. Sopian, S. Abdullah and M.S. Takriff, 2009. Experimental study of flow structures of circular pulsating air jet. Am. J. Eng. Applied Sci., 2: 171-175.

DOI: 10.3844 /ajeassp.2009.171.175

Zurfi, A. and J. Zhang, 2016a. Model identification and wall-plug efficiency measurement of white LED modules. Am. J. Eng. Applied Sci., 9: 412-419. DOI: 10.3844/ajeassp.2016.412.419

Zurfi, A. and J. Zhang, 2016b. Exploitation of battery energy storage in load frequency control-a literature survey. Am. J. Eng. Applied Sci., 9: 1173-1188. DOI: 10.3844/ajeassp.2016.1173.1188

\section{Source of Figures:}

\section{Figure 01:}

https://www.ecocranes.ro/wp-

content/uploads/2016/01/ECO5.jpg

Figure 02:

https://www.ecocranes.ro/wpcontent/uploads/2016/01/ECO3.jpg

Figure 03:

https://www.ecocranes.ro/wpcontent/uploads/2016/01/ECO6.jpg 